\title{
Appraising soil carbon storage potential under perennial and annual Chenopodiaceae in salt marsh of NE Spain
}

\author{
Maria Gispert $^{\mathrm{a},{ }^{*}, \text { Tetiana Kuliush }^{\mathrm{b}} \text {, Lina Dyachenko }{ }^{\mathrm{b}} \text {, Mykola Kharytonov }}{ }^{\mathrm{b}}$, Mohamed Emran ${ }^{\mathrm{c}}$, \\ Dolors Verdaguer $^{\mathrm{d}}$, Laura Llorens ${ }^{\mathrm{d}}$, Lorena Carrasco-Barea ${ }^{\mathrm{d}}$ \\ a Soil Science Unit, Department of Chemical Engineering, Agriculture, and Food Technology, University of Girona, C/ Maria Aurelia Capmany 61, 17003, Girona, Spain \\ ${ }^{\mathrm{b}}$ Dnipro State Agrarian and Economic University, Sergii Yefremov Str. 25, 49000, Dnipro, Ukraine \\ ${ }^{\mathrm{c}}$ Land and Water Technologies Department, Arid Lands Cultivation Research Institute, City of Scientific Research and Technological Applications (SRTA-City), New Borg \\ El-Arab City, 21934, Alexandria, Egypt \\ d Plant Physiology Unit, Department of Environmental Sciences, University of Girona, C/ Maria Aurelia Capmany 61, 17003, Girona, Spain
}

\section{A R T I C L E I N F O}

\section{Keywords:}

Salt marsh

Sarcocornia fruticosa (L.) Scott

Salicornia patula Duval Jouve

Above below and litter carbon

Soil organic carbon

Glomalin

Aggregate stability

Ecosystem service

\begin{abstract}
A B S T R A C T
The work was conducted at La Pletera salt marsh (NE Spain) to investigate the potential for atmospheric carbon capture of perennial Sarcocornia fruticosa (L.) Scott and annual Salicornia patula Duval Jouve and subsequent carbon integration and storage into $S$. fruticosa and $S$. patula soils respectively, at 0-5 and 5-20 cm depth. S. fruticosa amounts of aboveground (aC), belowground (bC) and litter (1C) carbon were $2300 \%, 350 \%$ and $3000 \%$ higher than $S$. patula according to the respective plant, root and litter biomass. This dramatic difference was reflected in soil organic carbon (SOC) values, much higher in $S$. fruticosa soil at 0-5 cm depth with $17.07 \pm$ $5.83 \mathrm{~g} \mathrm{~kg}^{-1}$ than $S$. patula soil with $5.89 \pm 1.68 \mathrm{~g} \mathrm{~kg}^{-1}$, namely $189 \%$ increase. Similarly, SOC increased by $109 \%$ in $S$. fruticosa soil at $5-20 \mathrm{~cm}$ depth. This perennial species can accumulate great amount of decaying debris at surface, which would gradually decompose by microbial activity to increase the soil organic carbon stock. Furthermore, the organic carbon incorporated is of better quality because contains higher fractions of glomalin, a stable organic compound known for its important role in soil aggregate stability. In fact, glomalin related soil protein (GRSP) was $292 \%$ and $182 \%$ higher in $S$. fruticosa than $S$. patula at the two depths respectively. By contrast, the low amount and nature of decaying debris produced in $S$. patula are easily mineralized and lesser organic carbon is consequently incorporated into soil. Lower SOC and GRSP affected the soil aggregate stability (WSA) in the $0.25-2 \mathrm{~mm}$ and 2-5.6 mm aggregate fractions, considerably more detachable in $S$. patula soil. Moreover, this soil exhibited the highest mineralization coefficient (Qm) at both depths, 125\% and 175\% higher than $S$. fruticosa soil respectively, and a major sensitivity to carbon loss. The PCA further highlighted the ability of $S$. fruticosa habitat to act as a carbon sink. Results may be valuable for salt marsh vegetation management addressed to mitigate climate change and increase ecosystem services.
\end{abstract}

\section{Introduction}

Salt marshes are important worldwide ecosystems with potential to mitigate climate change for their relevant role in the global carbon cycle (Mitsch et al., 2013). Climate change mitigation refers to efforts addressed to reduce atmospheric carbon dioxide by plant photosynthetic activity. Plant-soil interactions promote the transfer of assimilated C from plants to soil microbial biomass enhancing the role of soil as potential organic carbon sink (Chastain et al., 2018). About $20 \%-30 \%$ of the terrestrial organic carbon is attributed to salt marshes (Lal, 2008), but their importance is often disregarded (Bromberg Gedan et al., 2009). Salt marshes are found predominantly along coastlines with temperate climates and since many years have been gaining attention in soil carbon sequestration studies (Howe et al., 2009; González-Alcaraz et al., 2012). They cover approximately less than $7 \%$ of the earth's land surface and have shown great ability to capture atmospheric carbon through halophile vegetation (Čížková et al., 2011; Chmura, 2013) and contribute to carbon sequestration (Van de Broek et al., 2016). In the Mediterranean, salt marshes are in danger because affected by erosive processes due to

\footnotetext{
* Corresponding author.

E-mail addresses: maria.gispert@udg.edu (M. Gispert), kasiopea0110@gmail.com (T. Kuliush), linadyach@ukr.net (L. Dyachenko), kharytonov.m.m@dsau.dp.ua

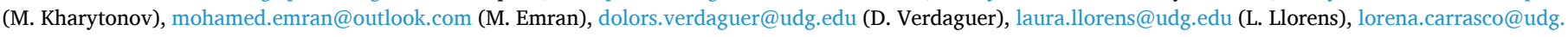
edu (L. Carrasco-Barea).
} 


$\begin{array}{ll}\text { Abbreviations } \\ \text { aC } & \text { aboveground biomass carbon } \\ \text { bC } & \text { belowground biomass carbon } \\ \text { BSA } & \text { bovine serum albumin } \\ \text { DBD } & \text { dried bulk density } \\ \text { EC } & \text { electrical conductivity } \\ \text { GRSP } & \text { glomalin related soil protein } \\ \text { HSD } & \text { honestly significant difference } \\ \text { IC } & \text { litter carbon } \\ \text { MLRM } & \text { multiple linear regression model } \\ \text { NT } & \text { total nitrogen } \\ \text { Qm } & \text { mineralization coefficient } \\ \text { RPM } & \text { revolution per minute } \\ \text { SCD } & \text { soil carbon density } \\ \text { SCS } & \text { soil carbon stock } \\ \text { SOC } & \text { soil organic carbon } \\ \text { WSA } & \text { water stable aggregates }\end{array}$

scarce but high intensity rainfall and very dry summer (Caravaca et al., 2005). Marsh vegetation may counteract surface erosion but its role is uncertain in reducing lateral erosion caused by wave impact in tidal marshes, resulting in removal of bank material (Marani et al., 2011). These effects may even increase due to sea level rise and change in tidal amplitudes in combination with reduced fluvial sediment supply (Leuven et al., 2019). Salt marsh degradation may also occur by plant competition induced by anthropic disturbance, ultimately causing bare patches after native halophytes extinction (Macreadie et al., 2013). In this regard, Deegan et al. (2012) found that fertilizers discharge in coastal ecosystems cause dramatic nutrients enrichment, overwhelming the marsh capacity to remove nitrogen, producing eutrophication and contributing to accelerated salt marsh loss. Moreover, salt marshes have gradually disappeared due to the increased value of land in the Mediterranean shoreline (Lefeuvre et al., 2003), which have favoured urbanization for tourism and lots of recreational activities (Spencer and Harvey, 2012). When these ecosystems are degraded, the stored carbon can be released and annual uptake of carbon dioxide ceases, thus moving backwards positive effects on climate change (Mcleod et al., 2011; Pendleton et al., 2012). Salt marshes need therefore to be protected as important natural habitats for plants and wildlife, because they constitute valuable food resources and provide many ecosystem services which benefits are extended to human life (Barbier et al., 2011). Plant/soil relationships are important in salt marshes because soil properties and halophytes characteristics and distribution may drive carbon incorporation to soil (Antisari et al., 2017). Several studies have reported the importance of above and below biomass in soil carbon accumulation (Tripathee and Schäfer, 2015). Other studies have separately quantified halophytes productivity to examine the relationships between plant growth, decay, and biomass in concert with soil carbon accumulation (Elsey-Quirk and Unger, 2018). Atmospheric carbon deposition in tidal salt marshes may be enhanced by allochthonous material (edaphic algae or dead wrack) related to sea level rise and sediments and nutrients supply (Saintilan et al., 2013), whilst non-tidal marshes in coastal lagoons with limited sediments supply may be particularly vulnerable because of their reliance on in situ organic matter production (Kirwan and Guntenspergen 2012). On the one hand, ecosystems with low sediments supply may therefore only rely on autochthonous plant carbon inputs (Craft et al., 2007) highlighting the relevance of local vegetation in managing carbon dynamics (Unger et al., 2016). On the other hand, Silvestri et al. (2018) suggested a renewing dynamics of salt marsh surface elevation related to local scale sediment input and output, balancing soil compaction and organic matter decomposition.
In the NE of Iberian Peninsula, residual brackish and hyperhaline salt marshes are still present and are separated from the sea almost all the year (Quintana, 2002). The isolation from surface freshwater and marine inputs define the characteristics of confined coastal lagoons alternated with sweep of salt marsh soils which hydrology has been thoroughly studied (Menció et al., 2017). Some of the most abundant plant communities of these ecosystems are mainly composed by Sarcocornia fruticosa (L.) Scott and by Salicornia patula Duval Jouve (Gesti, 2019). These two plant communities represent therefore an important contribution to autochthonous carbon deposition and accumulation in soils and deserve special attention in carbon sequestration studies at this site.

The research work was conducted at La Pletera salt marsh with the objective to elucidate the capacity of the perennial Sarcocornia fruticosa (L.) Scott and annual Salicornia patula Duval Jouve to absorb atmospheric carbon dioxide in above and belowground biomass and litter in relation to their soil organic carbon content. We hypothesise that the vegetation type can have a differential effect on patterns of soil organic carbon dynamics which in turn may largely regulate other relevant soil parameters such as glomalin and aggregate stability. As salt marsh areas are often postulated as potential carbon sink, the work seeks to explore the extent of contrasting plant communities to contribute to soil carbon accumulation and storage, suggesting the possibility of salt marsh management for improving atmospheric carbon capture.

\section{Materials and methods}

\subsection{Study area}

La Pletera salt marsh is located inside the Montgrí, Medes Islands and Baix Ter Natural Park ( $42^{\circ} 01^{\prime} 03^{\prime \prime} \mathrm{N}, 3^{\circ} 11^{\prime} 29^{\prime \prime} \mathrm{E}$ ), Estartit city, NE Spain (Fig. 1a and b). The site occupies an area of 7.5 ha and is included in Natura 2000 Network. The climate in the region is temperate humid with dry and hot summer. The annual average temperature is $16^{\circ} \mathrm{C}$ with an average maximum of $25^{\circ} \mathrm{C}$ in summer and minimum of $10^{\circ} \mathrm{C}$ in winter. Average rainfall is about $590 \mathrm{~mm}_{\text {year }}{ }^{-1}$ with higher rainfall (around $200 \mathrm{~mm}$ ) recorded in spring and autumn respectively. This confined Mediterranean coastal ecosystem hosts a well-preserved area with halophilic plant communities (Badosa et al., 2006). Two of the most abundant plant species that can be found in these plant communities belong to the Chenopodiaceae family and are Sarcocornia fruticosa (L.) Scott (hereafter S. fruticosa) and Salicornia patula Duval-Jouve (hereafter $S$. patula). Both species dominate two of the habitats that occupy the largest part of the Pletera but differ in physiological characteristics. $S$. fruticosa is a perennial shrub with woody stems procumbent to erect reaching up to $1 \mathrm{~m}$ high (Scarton et al., 2002). It is characterized by jointed branches with fleshy stems and a diffused root system with large amount of ligneous tissues, it forms dense stands along coasts with seasonally or permanently dry climate (Fig. 1c), and is common in loamy soils of Mediterranean salt marshes (Ibañez et al., 2000). S. patula is an annual small herbaceous plant with short erected fleshy shoots and reduced root density, and generally shows low cover percentage (Fig. 1d). It is mostly common in sandy soils of Mediterranean salt marshes (Šajna et al., 2013) and often also occurs in the clearings or on the edges of the areas colonized by the perennial glassworts. Below the two plant communities we find shallow soils (approximately no more than $30 \mathrm{~cm}$ depth), showing evidence of aquic conditions imposed by water table upwelling (Fig. 1e). The $S$. fruticosa soil was classified as Typic Fluvaquent and the $S$. patula soil as Typic Psammaquent (Soil Survey Staff, 2014). The A/C horizon development is much clearer in the $S$. fruticosa soil while is indistinct in the $S$. patula soil.

\subsection{Plant and soil sampling}

In each plant community five $100 \times 100 \mathrm{~cm}$ plots were established at 


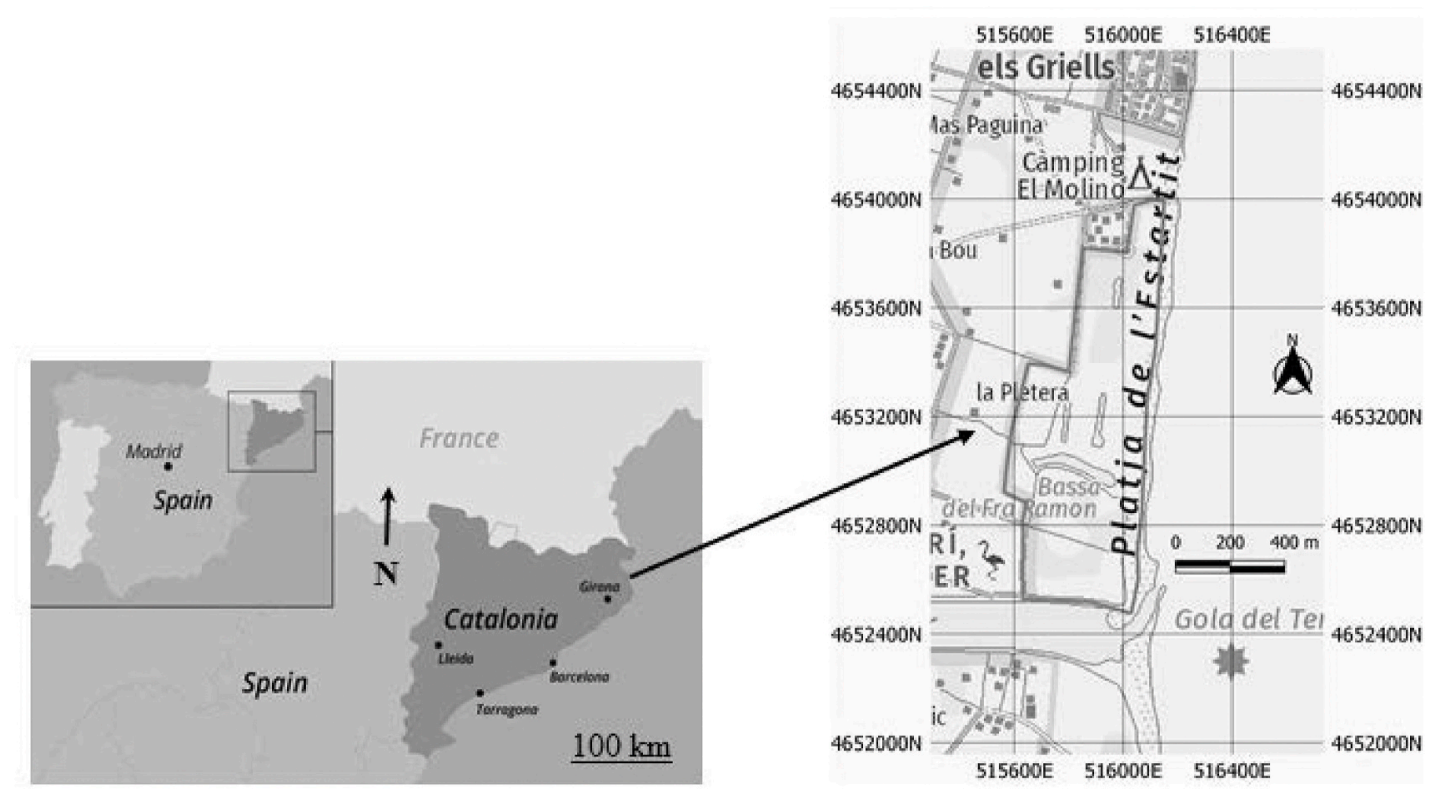

c Sarcocornia fruticosa(L.) Scott

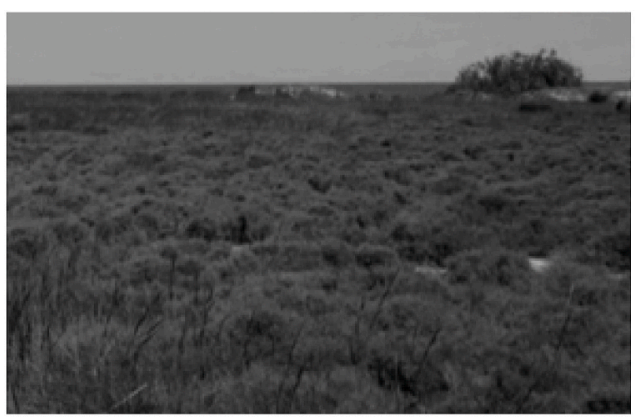

d Salicorniapatula Duval-Jouve

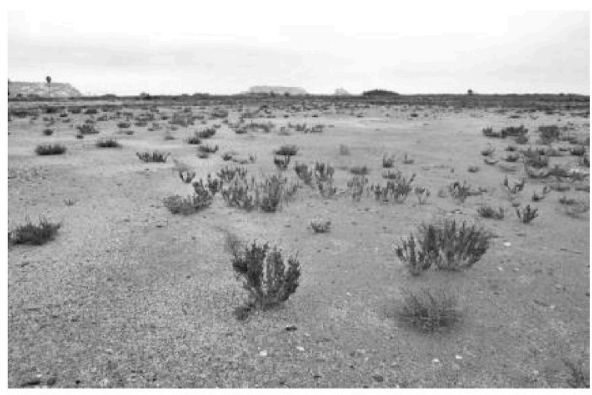

e Typic Fluvaquentat La Pletera

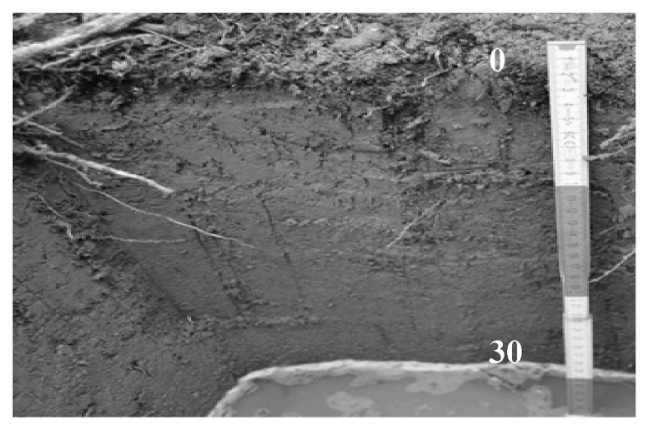

Fig. 1. Location of the Pletera salt marsh, Estartit city, Girona Province, SE Spain (a, b). Examples of $S$. fruticosa (c) and $S$. patula (d) habitats. Typical soil profile at La Pletera (e).

random. Before soil sampling, the percent plant cover of each square plot was established by registering the presence of vegetation in points separated by $10 \mathrm{~cm}$. Plant living biomass (stems and roots) and litter from each plot of both $S$. fruticos $a$ and $S$. patula were accurately sampled and taken to the laboratory. The three parts (roots, stems and litter) were thoroughly rinsed with tap water to remove any residual soil particles and separated. All the plant material was oven dried at $70{ }^{\circ} \mathrm{C}$ until constant weight. Samples were then prepared for subsequent analysis of aboveground carbon (aC), belowground carbon (bC) and litter carbon
(1C) of $S$. fruticosa and $S$. patula communities, respectively, from now on aC-S. fruticosa, bC-S. fruticosa, 1C-S. fruticosa and aC-S. patula, bCS. patula, 1C-S. patula.

Five composited soil samples were extracted with an Eijkelkamp hand auger (Eijkelkamp Soil and Water Equipment, The Netherlands) in each plot at $0-5$ and 5-20 cm to have 25 samples at each depth. Soils were named $S$. fruticosa soil and $S$. patula soil, respectively. In total, 100 soil samples were collected from the two plant communities. Samples were then transferred to the laboratory, air dried and gently crushed, 
and a part was sieved at $0-2 \mathrm{~mm}$ mesh (fine earth fraction) for physical and chemical analyses, that is: 50 samples at $0-5 \mathrm{~cm}$ and 50 samples at $5-20 \mathrm{~cm}$ depth. Another part was used for aggregate stability trials by sieving the soils through $0.25-2 \mathrm{~mm}$ and $2-5.6 \mathrm{~mm}$ mesh to obtain $0-25-$ $2 \mathrm{~mm}$ and $2-5.6 \mathrm{~mm}$ aggregate fractions. That is: 100 samples at $0-5 \mathrm{~cm}$ and 100 samples at 5-20 cm. Additionally, five composited fresh soil samples were collected from each plot at the two depths, transported to the laboratory, cleaned for roots and sticks and stored at $4{ }^{\circ} \mathrm{C}$ for biological analyses.

\subsection{Plant and litter analyses}

To estimate the carbon captured by $S$. fruticosa and $S$. patula communities, the previously prepared plant material was homogenized with an electric $(150 \mathrm{~W})$ stainless steel grinder (Taurus, Spain). Concretely for $S$. patula the plant material of each fraction (roots, stems and litter) was all homogenized. Conversely, since the collected samples (roots, stems and litter) of $S$. fruticosa presented a remarkably higher amount of biomass, it was homogenized the $25 \%$ of each fraction when the total weight was higher than $80 \mathrm{~g}$; the $50 \%$ when the weight was $15-80 \mathrm{~g}$ and $100 \%$ when the weight was lower than $15 \mathrm{~g}$. After that, a part of each homogenized material was further finely grounded $(<50 \mu \mathrm{m})$ using a ball mill (Mixer Mill MM 400, Retsch GmbH, Haan, Germany). Three subsamples of $4 \mathrm{mg}$ of each material were placed in tin capsules for carbon analyses. Total carbon estimations were performed at the University of California (UC Davis, Stable Isotope Facility, Davis, USA) using an elemental analyser (PDZ Europa ANCA-GSL, Sercon Ltd., Cheshire, UK) linked to a continuous flow isotope ratio mass spectrometer (PDZ Europa 20-20 IRMS, Sercon Ltd., Cheshire, UK) as reported by Diaz-Guerra et al. (2018). The carbon stored in both the living vegetation and litter $\left(\mathrm{gC} \mathrm{m}^{-2}\right)$ was quantified multiplying the carbon concentration $\left(\mathrm{mgC} \mathrm{g}^{-1}\right.$ ) by its total weight and results were expressed as $\mathrm{g} \mathrm{m}^{-2}$ of aC-S. fruticosa, bC-S. fruticosa, 1C-S. fruticosa and aC-S. patula, bC-S. patula, 1C-S. patula, respectively.

\subsection{Soil analyses}

The dried bulk density (DBD) was determined by using $5 \times 5 \mathrm{~cm}$ stainless steel cylinders (Forster, 1995; Setia et al., 2011) to extract unaltered soil portions, then dried overnight at $105^{\circ} \mathrm{C}$ and weighed at $0.01 \mathrm{~g}$ accuracy. DBD was calculated as follows:

$D B D_{\left(g / c m^{3}\right)}=m / r^{2} \pi h$

Where, DBD is the dried bulk density, $m$ the mass of soil ( $\mathrm{g}$ ), $\mathrm{r}$ and $\mathrm{h}$ the radius and height $(\mathrm{cm})$ of stainless steel cylinder, respectively.

Particle size analysis was determined in $0-2 \mathrm{~mm}$ soil fraction by the pipette method (Forster, 1995). The method of Kemper and Roseanu (1986) was performed to measure the water stability of aggregates by using the previously separated aggregates tested with the Wet Sieving Apparatus of Eijkelkamp Soil and Water Equipment, The Netherlands. Measurements were carried out as follows: aliquots of both $0.25-2 \mathrm{~mm}$ and $2-5.6 \mathrm{~mm}$ aggregate fractions were moistened with distilled water by capillary action, placed in $0.25 \mathrm{~mm}$ and $2 \mathrm{~mm}$ sieves respectively and then subjected to vertical oscillatory sieving during $3 \mathrm{~min}$ in cups of distilled water. Each immersion-emersion cycle lasted $3 \mathrm{~s}$, with a total of 60 cycles during $3 \mathrm{~min}$, causing disruption and detachment by the dispersive forces of water. Survived aggregates were dried at $105^{\circ} \mathrm{C}$ and weighed with accuracy of $0.01 \mathrm{~g}$. The stability of aggregates to water (WSA) was calculated for each fraction and depth from the following equation, taking into account the sand content:

$\operatorname{WSA}(\%)=\frac{\left(M_{(a+s)}-M_{s}\right)}{\left(M_{t}-M_{s}\right)} 100$

Where, $M_{(a+s)}$ is the mass of the resistant aggregates plus sand $(g), M_{s}$ is the mass of the sand fraction alone $(\mathrm{g})$, and $\mathrm{M}_{\mathrm{t}}$ is the total mass of the soil sample (g).

The fine earth fraction ( $0-2 \mathrm{~mm}$ ) was used to determine $\mathrm{pH}$ in 1:2.5 $(\mathrm{w} / \mathrm{v})$ soil water suspension and electrical conductivity (EC) on saturated paste extracts by means of a Dyson pH-meter and a CON 510 conductivity meter respectively (Forster, 1995) of Dyson-Eutech Instruments, Spain. Similarly, the soil organic carbon (SOC) was determined by the dichromate oxidation method (Walkley and Black 1934) and total nitrogen (NT) according to the Kjeldhal method (Bremner and Mulvaney, 1986).

Glomalin related soil protein (GRSP) was determined according to Rillig (2004) by placing $1 \mathrm{~g}$ of the fine earth fraction and $8 \mathrm{ml}$ of a $50 \mathrm{mM}$ trisodium citrate dihydrate solution at $\mathrm{pH} 8.0$ in centrifuge tubs then autoclaved at $121{ }^{\circ} \mathrm{C}$ for $60 \mathrm{~min}$. After extraction, samples were centrifuged at 5000 RPM for $15 \mathrm{~min}$ and the supernatant collected and stored at $4{ }^{\circ} \mathrm{C}$. Extractions were continued on the same samples until pale-yellow supernatants were obtained indicating absence of glomalin (Nichols and Wright, 2005). Extracts were pooled together and glomalin quantified by the Bradford protein assay (Sigma Aldrich) with bovine serum albumin (BSA) as the standard. The glomalin quantification is based on the reaction of Coomassie Brilliant Blue (CBB) G-250 acidic solution binding to the BSA protein thus altering the absorbance properties of the dye. A total of $0.04 \mathrm{ml}$ of BSA standard solutions $(0,25,50$, $100,200 \mu \mathrm{g} \mathrm{mL}^{-1}$ ) was added to a $2 \mathrm{ml}$ of $1: 4(\mathrm{v} / \mathrm{v})$ acidic solution. The addition of protein results in a shift of the dye absorption from 465 to $595 \mathrm{~nm}$, causing a visible colour change detected by spectrophotometric measurements. Similarly, $0.04 \mathrm{~mL}$ of the glomalin-extracted solution (containing the glycoprotein) was used to measure the unknown glomalin concentration of the soil samples. The assay is useful because the extinction coefficient of the dye-albumin complex solution is constant over a suitable concentration range (Bradford, 1976).

The respiration of the soil was determined according to Keith and Wong (2006). $150 \mathrm{~g}$ of unaltered fresh soil samples collected at $0-5$ and $5-20 \mathrm{~cm}$ depth were placed in $500 \mathrm{~cm}^{3}$ glass jar containing porcelain cups with $15 \mathrm{~g}$ of soda lime, previously oven dried at $105{ }^{\circ} \mathrm{C}$ and weighed with the accuracy of $0.001 \mathrm{mg}$. Samples were then incubated during 7 day at $25{ }^{\circ} \mathrm{C}$ at dark. After incubation soda lime was dried overnight at $105{ }^{\circ} \mathrm{C}$, cooled in a desiccator and weighed with the accuracy of $0.001 \mathrm{mg}$. The method of Grogan (1998) was followed for the appropriate correction for water formed during $\mathrm{CO}_{2}$ adsorption on soda lime. Each mole of $\mathrm{CO}_{2}$ is bound with soda lime together with a mole of water, successively lost by oven drying. Dry mass increase before and after exposure would therefore underestimate the $\mathrm{CO}_{2}$ absorbed. The correction factor takes into account that $44 \mathrm{~g}$ of $\mathrm{CO}_{2}$ reacts with $74 \mathrm{~g}$ of $\mathrm{Ca}(\mathrm{OH})_{2}$ forming $100 \mathrm{~g}$ of $\mathrm{CaCO}_{3}$ and $18 \mathrm{~g}$ of water. The weight increase in soda lime is then 26 (i.e. 100-74), which gives the correction factor of $44 / 26=1.69$ to be applied to the mass difference in order to obtain the true value of $\mathrm{CO}_{2}$ absorbed. Values were then expressed as $\mathrm{mg} \mathrm{CO}_{2} \mathrm{~g}^{-1}$ day $^{-1}$. Carbon of carbon dioxide $\left(\mathrm{C}-\mathrm{CO}_{2}\right)$ may be then calculated as follows:

$\mathrm{C}-\mathrm{CO}_{2}=\mathrm{CO}_{2} \times 12 / 44$

Where 12 and 44 are the molecular weights of carbon and carbon dioxide respectively.

Once obtained the $\mathrm{C}-\mathrm{CO}_{2}$ values the mineralization coefficient $\mathrm{Qm}$ of soil organic carbon can be derived according to Dommergues (1960):

$Q m=C-\mathrm{CO}_{2} / \mathrm{SOC}$

Where SOC is the soil organic carbon.

The soil carbon density and carbon stocks were estimated according to Chastain et al. (2018). For each soil-plant habitat the average soil carbon stock (Mg SOC ha-1) were obtained by first measuring the soil carbon density (SCD, g SOC $\mathrm{cm}^{-3}$ ) in the $0-5$ and $5-20 \mathrm{~cm}$ depth as follows:

$S C D_{\left(g S O C \mathrm{~cm}^{-3}\right)}=S O C / 100 \times D B D$ 
SCD is the mass of carbon found in the two soil layers, SOC is the soil organic carbon and DBD is the dried bulk density.

\subsection{Data analysis}

The program Statistics (Version 7.1, 2007, Statsoft Inc., Tulsa, OK, USA) was used for data analysis. One way ANOVA and Tukey HSD posthoc test was tried to check significant data variability within and between the soil habitats along the two investigated depths.

Also, to establish the degree of variation of soil organic compounds and structural stability, multiple regression equations were performed by assessing the effect of the independent variables sand, silt+clay, DBD and $\mathrm{pH}$ on SOC, GRSP, NT, $\mathrm{CO}_{2}, \mathrm{Qm}, \mathrm{WSA}_{(0.25-2)}$ and $\mathrm{WSA}_{(2-5.6)}$ as dependent variables and the model was set as follows using data of $0-20$ cm depth for each soil habitat:

$$
\begin{aligned}
& Y_{S O C}, Y_{G R S P}, Y_{N T}, Y_{C O_{2}}, Y_{Q m}, Y_{W S A(0.25-2)}, Y_{W S A(2-5.6)}=\beta_{0}+\beta_{1} X_{\text {sand }}+\beta_{2} X_{\text {silt }+ \text { clay }} \\
& \quad+\beta_{3} X_{D B D}+\beta_{4} X_{p H}
\end{aligned}
$$

Which may be more clearly read by using the next array formulation:

$$
\left[\begin{array}{l}
Y_{1} \\
Y_{2} \\
Y_{3} \\
Y_{4} \\
Y_{5} \\
Y_{6} \\
Y_{7}
\end{array}\right]=\beta_{0}\left[\begin{array}{l}
1 \\
1 \\
1 \\
1 \\
1 \\
1 \\
1
\end{array}\right]+\beta_{1}\left[\begin{array}{l}
X_{11} \\
X_{21} \\
X_{31} \\
X_{41} \\
X_{51} \\
X_{61} \\
X_{71}
\end{array}\right]+\beta_{2}\left[\begin{array}{l}
X_{12} \\
X_{22} \\
X_{32} \\
X_{42} \\
X_{52} \\
X_{62} \\
X_{72}
\end{array}\right]+\beta_{3}\left[\begin{array}{l}
X_{13} \\
X_{23} \\
X_{33} \\
X_{43} \\
X_{53} \\
X_{63} \\
X_{73}
\end{array}\right] \beta_{4}\left[\begin{array}{l}
X_{14} \\
X_{24} \\
X_{34} \\
X_{44} \\
X_{54} \\
X_{64} \\
X_{74}
\end{array}\right]
$$

Where $\mathrm{Y}_{1}, \mathrm{Y}_{2}, \mathrm{Y}_{3}, \mathrm{Y}_{4}, \mathrm{Y}_{5}, \mathrm{Y}_{6}$ and $\mathrm{Y}_{7}$ represent SOC, GRSP, NT, $\mathrm{CO}_{2}, \mathrm{Qm}$, $\mathrm{WSA}_{(0.25-2)}$ and $\mathrm{WSA}_{(2-5.6)}$ respectively, the first subscript in $\mathrm{X}$ represents the observation related to each dependent variable, the second subscript in $\mathrm{X}$ each independent variable (sand, silt+clay, $\mathrm{DBD}$ and $\mathrm{pH}$ ) respectively and $\beta_{0}, \beta_{1}, \beta_{2}, \beta_{3}, \beta_{4}$ represent partial regression coefficients.

Moreover, principal component analysis (PCA) was carried out to create a component structure with variables responsible for most of the global variance of data. Scoring each component with associated variables and matching them with the soil habitats provided information about the relationships between soils and variables to emphasize trends of soil properties and carbon storage in the studied area.

\section{Results}

\subsection{Plant and soil patterns}

On average, the plant cover estimated through visual inspection of the presence or absence of vegetation every $10 \mathrm{~cm}$ within each plot was $98 \%$ in $S$. fruticosa and $78 \%$ in S. patula. This was reflected in the mean values of above, below and litter carbon $(\mathrm{aC}, \mathrm{bC}$ and $\mathrm{lC}$ ) of the two plant communities. The aC-S. fruticosa amounted to $1573.52 \pm 823.87 \mathrm{~g} \mathrm{~m}^{-2}$, i.e. $2285 \%$ higher than aC-S. patula with $65.98 \pm 7.18 \mathrm{~g} \mathrm{~m}^{-2}$. Similarly, bC-S. fruticosa was $89.73 \pm 16.45 \mathrm{~g} \mathrm{~m}^{-2}$ against $19.91 \pm 7.39 \mathrm{~g} \mathrm{~m}^{-2}$ of bC-S. patula, i.e. $350 \%$ higher. Therefore, the higher vegetation density of $S$. fruticosa leads to enhanced $\mathrm{CO}_{2}$ capture with respect to $S$. patula. The litter carbon (1C) followed the same trend and resulted $233.24 \pm$ $104.76 \mathrm{~g} \mathrm{~m}^{-2}$ in $S$. fruticosa, $3000 \%$ higher than $1 \mathrm{C}$ of $S$. patula with 7.53 $\pm 4.70 \mathrm{~g} \mathrm{~m}^{-2}$.

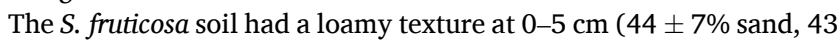
$\pm 9 \%$ silt, $13 \pm 9 \%$ clay) and sandy loam at $5-20 \mathrm{~cm}$ ( $55 \pm 11 \%$ sand, 33 $\pm 7 \%$ silt, $7 \pm 3 \%$ clay). The $S$. patula soil texture was loamy sand all along $0-20 \mathrm{~cm}$ depth (78 $\pm 14 \%$ sand, $16 \pm 7 \%$ silt, $6 \pm 3 \%$ clay), and textural values corroborated soil classification. Mean soil parameters of the studied habitats are reported in Table 1 . Average values of dried bulk density (DBD) ranged between 1.27 and $1.35 \mathrm{~g} \mathrm{~cm}^{-3}$ and varied significantly $(\mathrm{p}<0.05)$ between depths within a same plant community, and between the plant communities only at $0-5 \mathrm{~cm}$ depth. Soil $\mathrm{pH}$ was moderately alkaline $(7.92 \div 8.57)$ and values were significant $(\mathrm{p}<0.05)$ within $S$. fruticosa soil at different depths and between $S$. fruticosa and $S$. patula soils at $0-5 \mathrm{~cm}$ depth. Soil electrical conductivity (EC) showed significant variation $(\mathrm{p}<0.05)$ within each plant community at different depths, but not at the same depth when comparing values of the two plant communities (Table 1). Effectively, EC values were very similar between $S$. fruticosa and $S$. patula soils at $0-5 \mathrm{~cm}\left(12.52 \pm 0.17 \mathrm{dS} \mathrm{m}^{-1}\right.$ and $\left.11.22 \pm 3.55 \mathrm{dS} \mathrm{m}^{-1}\right)$ and at $5-20 \mathrm{~cm}\left(4.10 \pm 1.50 \mathrm{dS} \mathrm{m}^{-1}\right.$ and 4.47 $\pm 1.44 \mathrm{dS} \mathrm{m}^{-1}$ ). These values decreased by $68 \%$ and $61 \%$ respectively from $0-5$ to $5-20 \mathrm{~cm}$ in both soils probably indicating the presence of salt efflorescences at soil surface during dry periods (Antisari et al., 2017). Calcium carbonate content was rather constant along depths (10.35 \pm $3.39 \%$ and $10.23 \pm 1.69 \%$ ) in both soils and was mainly composed by residual shells and calcareous sandstone particles deposited in the study area. Values of SOC, NT and GRSP varied significantly $(\mathrm{p}<0.05)$ within and between both $S$. fruticosa and $S$. patula soils at different depths

Table 1

\begin{tabular}{|c|c|c|c|c|c|c|c|c|c|c|c|}
\hline Soil & DBD & $\mathrm{pH}$ & EC & SOC & NT & GRSP & $\mathrm{WSA}_{(0.25-2)}$ & $\mathrm{WSA}_{(2-5.6)}$ & $\mathrm{CO}_{2}$ & $\mathrm{C}-\mathrm{CO}_{2}$ & Qm \\
\hline & $\left(\mathrm{g} \mathrm{cm}^{-3}\right)$ & & $\left(\mathrm{dS} \mathrm{m} \mathrm{m}^{-1}\right)$ & $\left(\mathrm{g} \mathrm{kg}^{-1}\right)$ & $\left(\mathrm{g} \mathrm{kg}^{-1}\right)$ & $\left(\mathrm{g} \mathrm{kg}^{-1}\right)$ & (\%) & (\%) & $\left(\mathrm{g} \mathrm{kg}^{-1}\right)$ & $\left(\mathrm{g} \mathrm{kg}^{-1}\right)$ & \\
\hline S. fruticosa soil ${ }_{5}-$ & $\begin{array}{l}1.27 \pm \\
0.13\end{array}$ & $\begin{array}{l}7.92 \pm \\
0.21\end{array}$ & $\begin{array}{l}12.52 \pm \\
0.17\end{array}$ & $\begin{array}{l}17.07 \pm \\
5.83\end{array}$ & $\begin{array}{l}0.78 \pm \\
0.23\end{array}$ & $\begin{array}{l}3.22 \pm \\
0.85\end{array}$ & $78.85 \pm 8.03$ & $\begin{array}{l}87.16 \pm \\
8.36\end{array}$ & $\begin{array}{l}0.50 \pm \\
0.04\end{array}$ & $\begin{array}{l}0.13 \pm \\
0.03\end{array}$ & $\begin{array}{l}0.008 \pm \\
0.003\end{array}$ \\
\hline $\begin{array}{l}\text { S. fruticosa soil } \\
5-\end{array}$ & $\begin{array}{l}1.34 \pm \\
0.28 \\
a b\end{array}$ & $\begin{array}{l}8.40 \pm \\
0.66 \\
a b\end{array}$ & $\begin{array}{l}4.10 \pm \\
1.50 \\
a b\end{array}$ & $\begin{array}{l}6.64 \pm \\
2.33 \\
a b\end{array}$ & $\begin{array}{l}0.29 \pm \\
0.11 \\
a b\end{array}$ & $\begin{array}{l}0.62 \pm \\
0.20 \\
a b\end{array}$ & $\begin{array}{l}43.10 \pm 9.88 \\
\mathrm{ab}\end{array}$ & $\begin{array}{l}29.41 \pm \\
7.96 \\
\mathrm{ab}\end{array}$ & $\begin{array}{l}0.08 \pm \\
0.02 \\
a b\end{array}$ & $\begin{array}{l}0.02 \pm \\
0.01 \\
a b\end{array}$ & $\begin{array}{l}0.004 \pm \\
0.002 \\
\mathrm{ab}\end{array}$ \\
\hline S. patula soil ${ }_{0-5}$ & $\begin{array}{l}1.31 \pm \\
0.14\end{array}$ & $\begin{array}{l}8.47 \pm \\
0.16\end{array}$ & $\begin{array}{l}11.22 \pm \\
3.55\end{array}$ & $\begin{array}{l}5.89 \pm \\
1.68\end{array}$ & $\begin{array}{l}0.40 \pm \\
0.13\end{array}$ & $\begin{array}{l}0.82 \pm \\
0.12\end{array}$ & $\begin{array}{l}55.28 \pm \\
11.30\end{array}$ & $\begin{array}{l}45.83 \pm \\
17.72\end{array}$ & $\begin{array}{l}0.38 \pm \\
0.05\end{array}$ & $\begin{array}{l}0.11 \pm \\
0.02\end{array}$ & $\begin{array}{l}0.018 \pm \\
0.005\end{array}$ \\
\hline S. patula soil ${ }_{5-20}$ & $\begin{array}{l}1.35 \pm \\
0.18 \\
a b\end{array}$ & $\begin{array}{l}8.57 \pm \\
0.42 \\
\text { aа }\end{array}$ & $\begin{array}{l}4.47 \pm \\
1.44 \\
a b\end{array}$ & $\begin{array}{l}3.17 \pm \\
1.10 \\
a b\end{array}$ & $\begin{array}{l}0.19 \pm \\
0.06 \\
a b\end{array}$ & $\begin{array}{l}0.22 \pm \\
0.08 \\
a b\end{array}$ & $\begin{array}{l}33.66 \pm \\
11.67 \\
\mathrm{ab}\end{array}$ & $\begin{array}{l}15.63 \pm \\
8.28 \\
a b\end{array}$ & $\begin{array}{l}0.11 \pm \\
0.04 \\
a b\end{array}$ & $\begin{array}{l}0.03 \pm \\
0.01 \\
a b\end{array}$ & $\begin{array}{l}0.011 \pm \\
0.004 \\
\mathrm{ab}\end{array}$ \\
\hline $0-5 \mathrm{~cm}$ & $\mathrm{AB}$ & $\mathrm{AB}$ & AA & $\mathrm{AB}$ & $\mathrm{AB}$ & $\mathrm{AB}$ & $\mathrm{AB}$ & $\mathrm{AB}$ & $\mathrm{AB}$ & $\mathrm{AB}$ & $\mathrm{AB}$ \\
\hline $5-20 \mathrm{~cm}$ & AA & AA & AA & $\mathrm{AB}$ & $\mathrm{AB}$ & $\mathrm{AB}$ & $\mathrm{AB}$ & AA & AA & $\mathrm{AA}$ & $\mathrm{AB}$ \\
\hline
\end{tabular}

Relevant soil parameters determined at $0-5$ and $5-20 \mathrm{~cm}$ depth in the investigated habitats at La Pletera salt marsh site. Significant variability is checked by one way Anova. SE of the mean $(n=25)$ is given.

DBD: Dried bulk density; EC: Electrical conductivity; SOC: Soil organic carbon; NT: Total nitrogen; GRSP: Glomalin related soil protein; WSA $(0.25-2)$ : Structural stability of aggregates in the $0.25-2 \mathrm{~mm}$ aggregate fraction; $\mathrm{WSA}_{(2-5.6)}$ : Structural stability of aggregates in the $2-5.6 \mathrm{~mm}$ aggregate fraction; $\mathrm{CO}_{2}$ : Carbon dioxide emission potential; $\mathrm{C}-\mathrm{CO}_{2}$ : Carbon of carbon dioxide; Qm: Mineralization coefficient.

Different lower case letters indicate significant differences of soil parameters within each plant community at different depths; In the last rows capital letters indicate significant differences of soil parameters between plant communities at each depth; Statistical difference estimated by Tukey HSD post-hoc test, $\mathrm{p}<0.05$. 
(Table 1). SOC, NT and GRSP values increased by $189 \%$, $95 \%$ and $292 \%$ at $0-5 \mathrm{~cm}$ depth and by $109 \%, 52 \%$ and $182 \%$ at $5-20 \mathrm{~cm}$ depth in $S$. fruticosa soil with respect to $S$. patula soil. In the majority of the analyzed parameters of both soils, significant decrease in the range of $38 \%-84 \%$ was detected at 5-20 cm depth. In particular SOC decreased by $61 \%$ and $46 \%$ in $S$. fruticos $a$ and $S$. patula soils, respectively (Table 1 ). The water stability of aggregates (WSA) varied significantly $(\mathrm{p}<0.05)$ within depths in both aggregate fractions of $S$. fruticosa and $S$. patula soils and between them at $0-5 \mathrm{~cm}$, but not at $5-20 \mathrm{~cm}$ in the $2-5.6 \mathrm{~mm}$ fraction (Table 1). At $0-5 \mathrm{~cm}$ depth mean WSA values of $S$. fruticosa soil increased by $43 \%$ and $90 \%$ in both $0.25-2 \mathrm{~mm}$ and $2-5.6 \mathrm{~mm}$ aggregate fractions with respect to $S$. patula soil. At 5-20 cm depth WSA values of both aggregate fractions were still higher in S. fruticosa (28\% and $88 \%$ respectively) than $S$. patula soil, suggesting that soil peds need appropriate amounts of organic aggregating agents to secure suitable structural stability.

\section{Discussion}

The values of aC, bC and $1 \mathrm{C}$ of $S$. fruticosa were in agreement with field observations and largely exceeded those of $S$. patula. This picture points out the relevant difference of primary production between the two plant communities, and the role of photosynthetic uptake of atmospheric $\mathrm{CO}_{2}$ later on transferred to soils as organic carbon via microbial activity (Curcó et al., 2002; Hopkins et al., 2014). The higher vegetation density and copious decaying debris contributed to improve by $120 \%$ the finer particles in $S$. fruticosa soil texture, justifying its classification as Typic Fluvaquent, in contrast with sparser plant distribution of $S$. patula which loamy sand soil was classified as Typic Psammaquent (Soil Survey Staff, 2014). The variability of soil parameters checked by one way Anova was somewhat more significant within each plant community at different depths though relevant SOC, NT, GRSP, WSA and Qm varied significantly between plant communities at each depth. Indeed, SOC, NT and GRSP values were considerably high at La Pletera salt marsh and particularly in $S$. fruticosa soil (Table 1). Other authors have reported lower values of SOC, NT and glomalin in similar ecosystems. Pei et al. (2019) recorded $2.30 \pm 0.17 \mathrm{~g} \mathrm{~kg}^{-1}$ glomalin in coastal wetlands inferring that glomalin content was significantly affected by the vegetation types. WenYang et al. (2019), obtained 3.43 $\pm 0.33 \mathrm{~g} \mathrm{~kg}^{-1}$ and $0.24 \pm 0.02 \mathrm{~g} \mathrm{~kg}^{-1}$ of SOC and NT respectively in a Chinese salt marsh mainly vegetated by Phragmites australis. In a Mediterranean salt marsh mainly covered by Arthrocnemum macrostachyum, Halimione portulacoides, and Suaeda vera, Caravaca et al. (2005) recorded SOC and TN values of $4.30 \pm 040 \mathrm{~g} \mathrm{~kg}^{-1}$ and $0.61 \pm 0.2 \mathrm{~g} \mathrm{~kg}^{-1}$ respectively. La Pletera salt marsh would thus deserve much attention for its much higher soil carbon, nitrogen and glomalin content, which also may imply added ecological values. Jobbágy and Jackson (2000) claimed a better understanding of the vertical distribution of SOC and how vegetation may affect it along soil depth through patterns of allocation. They showed that the relative distribution of SOC in the uppermost $20 \mathrm{~cm}$ was $33 \%, 42 \%$, and $50 \%$ in shrublands, grasslands and forests respectively, but shrublands had a larger SOC distribution below $20 \mathrm{~cm}$ due to denser above and below biomass which may preserve more organic carbon for longer. They even suggested site management through shrub encroachment of grasslands or afforestation to achieve carbon deep in the soil acting as a potential C sink. Hence, the allocation of vegetation is important for SOC distribution and associated parameters like NT and GRSP and ultimately soil aggregation and structural stability. Other authors (Bai et al., 2016) observed a decreasing trend of SOC distribution in deeper soil layers of salt marshes, suggesting that vegetation type and plant cycling may affect distribution pattern of SOC. In addition, they also reported that water content, texture, soil $\mathrm{pH}$ and salinity explained about $80 \%$ of SOC variation in the top $20 \mathrm{~cm}$ and $20-100 \mathrm{~cm}$ of soil layers. On the one hand, the consistent vertical decrease of values showed in Table 1 may warn on soil impoverishment in such restricted depth difference. On the other hand, values reported in
Table 1 enhance the importance of $S$. fruticosa vs. $S$. patula community showing the former much higher soil carbon content $(+65 \%)$, which may be thoroughly beneficial to others soil properties. These differences in soil carbon content would be closely related with the different type of vegetation that dominates each soil. As commented above, $S$. fruticosa forms dense banks of vegetation reaching up to $1.5 \mathrm{~m}$ high (Castroviejo, 1990) while areas dominated by $S$. patula are characterized by the presence of spaced individuals of usually no more than $40 \mathrm{~cm}$ height (Valdés and Castroviejo, 1990). This is in accordance with plant cover results and with the remarkably higher amount of carbon observed in the aboveground, litter and belowground biomass of $S$. fruticosa compared with $S$. patula. Hence, $S$. fruticosa soil receives a remarkably higher carbon input from vegetation compared with $S$. patula soil. In this sense, the vegetal material reaching the soil, decomposing and then contributing to the integration of organic carbon in the soil is mainly roots and litter. Previously, it has been observed that roots and woody stems of $S$. fruticosa, which represented the main fraction of the litter of this species (Ibañez et al., 1999), decompose slow (Curcó et al., 2002; Scarton et al., 2002), favoring therefore the humification and soil integration of the organic carbon from vegetal material instead of their total mineralization. Thus, $S$. fruticosa soil not only received a higher amount of carbon from vegetation but also the chemical quality of the vegetal material that reach the soil would guarantee the carbon incorporation on it. These results agree with the positive correlation observed in the case of $S$. fruticosa soil among the carbon of all the vegetal compartment (aC, bC and 1C) and SOC, GRSP and NT (Table 2). By contrast, the low amount and nature of decaying debris produced in $S$. patula are easily mineralized. The little contribution that the vegetation of $S$. patula has in carbon incorporation to soil can be observed in the absence of significant correlation among this parameter and $\mathrm{aC}, \mathrm{bC}$ and $\mathrm{IC}$ (Table 2).

As expected, at higher SOC and GRSP corresponded higher WSA in the two analyzed aggregate fractions and WSA values were always higher in S. fruticosa than S. patula soil (Table 1). Meanwhile, it was also observed that WSA values in the $0.25-2 \mathrm{~mm}$ aggregate fraction decreased by $45 \%$ and $39 \%$ with depth in both $S$. fruticosa and S. patula soils and the decline was even higher $(65 \%$ and $66 \%)$ in the $2-5.6 \mathrm{~mm}$ aggregate fraction (Table 1 ). Independently of the expected difference in WSA values between the two soils, it seems interesting to notice that the WSA percent decrease (from 0-5 to 5-20 cm depth) in the $2-5.6 \mathrm{~mm}$ fraction of $S$. fruticosa and $S$. patula soil is $32 \%$ and $40 \%$ respectively higher than in the $0.25-2 \mathrm{~mm}$ fraction. As the agents responsible for aggregate stability are mainly organic, and hence biological in origin (Caravaca et al., 2005), the decrease was ascribed to the abrupt decline of SOC (61\% and 46\%) and GRSP (80\% and 76\%) mainly affecting coarser aggregates. In fact, previous research on soil aggregate stability indicated that the reduction of soil organic carbon may affect coarser aggregates which are generally detached into smaller aggregates where SOC can be better protected (Oades, 1984). Some authors (Cerdà, 1998; Castellano et al., 2015) have reported that the type of litter and soil organic matter stabilization may have great relevance on soil organic carbon quality and quantity, thus influencing organo-mineral complexes and ultimately soil structure stability. Also, Totsche et al. (2018) outlined that appropriate amounts of organic compounds may create a stable soil crumb in which microaggregates may better withstand dispersion forces of water and last for centuries.

Values of potential soil respiration demonstrated that at higher organic carbon content corresponds higher $\mathrm{CO}_{2}$ production thereby increasing $\mathrm{C}-\mathrm{CO}_{2}$ (Table 1 ). In spite of this, $S$. patula soil had a much higher mineralization coefficient Qm (ratio $\mathrm{C}-\mathrm{CO}_{2} / \mathrm{SOC}$ ) which was $125 \%$ and $175 \%$ higher than $S$. fruticosa soil at both depths respectively, implying that the organic carbon pool considered a highly valued ecosystem property (Schmidt et al., 2011), may be mostly labile and easily mineralized in $S$. patula soil. Gasparri et al. (2016) reported that $S$. patula occurs on sandy-loam soils in the clearings or on the edges of areas colonized by stronger perennials, inferring that its annual characteristics with typical small bush growth reduce litter formation and 
Table 2

Correlation matrixes for variables of $S$. fruticosa and $S$. patula soils mediated along the $0-20 \mathrm{~cm}$ depth $(\mathrm{n}=50)$.

\begin{tabular}{|c|c|c|c|c|c|c|c|c|c|c|c|c|c|c|c|}
\hline $\begin{array}{l}\text { S. fruticosa } \\
\text { soil }\end{array}$ & Sand & Silt & Clay & DBD & $\mathrm{pH}$ & EC & SOC & GRSP & NT & $\begin{array}{l}\operatorname{WSA}_{(0.25-} \\
2)\end{array}$ & $\begin{array}{l}\mathrm{WSA}_{(2-} \\
5.6)\end{array}$ & $\mathrm{CO}_{2}$ & $\mathrm{Qm}$ & $\mathrm{aC}$ & $\mathrm{bC}$ \\
\hline Silt & $-0.78^{b}$ & & & & & & & & & & & & & & \\
\hline Clay & $-0.82^{b}$ & $0.77^{\mathrm{b}}$ & & & & & & & & & & & & & \\
\hline DBD & $0.78^{\mathrm{b}}$ & $-0.84^{\mathrm{b}}$ & $-0.74^{\mathrm{a}}$ & & & & & & & & & & & & \\
\hline $\mathrm{pH}$ & $0.81^{\mathrm{b}}$ & $-0.85^{\mathrm{b}}$ & $-0.77^{b}$ & 0.55 & & & & & & & & & & & \\
\hline EC & -0.47 & $0.73^{\mathrm{a}}$ & $0.79^{\mathrm{b}}$ & 0.02 & -0.09 & & & & & & & & & & \\
\hline SOC & $-0.83^{\mathrm{b}}$ & $0.76^{\mathrm{b}}$ & $0.85^{\mathrm{b}}$ & -0.49 & $-0.94^{c}$ & 0.35 & & & & & & & & & \\
\hline GRSP & $-0.92^{c}$ & $0.84^{\mathrm{b}}$ & $0.82^{\mathrm{b}}$ & -0.43 & $-0.95^{c}$ & 0.19 & $0.95^{c}$ & & & & & & & & \\
\hline NT & $-0.85^{b}$ & $0.87^{\mathrm{b}}$ & $0.80^{\mathrm{b}}$ & -0.38 & $-0.93^{c}$ & 0.25 & $0.95^{c}$ & $0.96^{c}$ & & & & & & & \\
\hline $\operatorname{WSA}_{(0.25-2)}$ & $-0.91^{c}$ & $0.95^{c}$ & $0.90^{c}$ & -0.55 & -0.47 & -0.26 & 0.26 & 0.31 & 0.31 & & & & & & \\
\hline $\mathrm{WSA}_{(2-5.6)}$ & $-0.97^{c}$ & $0.74^{\mathrm{a}}$ & $0.77^{\mathrm{b}}$ & $-0.68^{\mathrm{a}}$ & $-0.84^{\mathrm{b}}$ & 0.09 & $0.70^{\mathrm{a}}$ & $0.74^{\mathrm{a}}$ & $0.74^{\mathrm{a}}$ & $0.77^{\mathrm{b}}$ & & & & & \\
\hline $\mathrm{CO}_{2}$ & $-0.88^{b}$ & $0.76^{\mathrm{b}}$ & $0.69^{\mathrm{a}}$ & $-0.68^{\mathrm{a}}$ & $-0.91^{\mathrm{c}}$ & 0.17 & $0.87^{\mathrm{b}}$ & $0.92^{\mathrm{c}}$ & $0.84^{\mathrm{b}}$ & 0.31 & $0.79^{\mathrm{b}}$ & & & & \\
\hline $\mathrm{Qm}$ & $-0.75^{\mathrm{a}}$ & $0.78^{\mathrm{b}}$ & $0.72^{\mathrm{a}}$ & -0.56 & $-0.88^{\mathrm{b}}$ & -0.31 & $-0.94^{\mathrm{c}}$ & $-0.89^{b}$ & $-0.92^{\mathrm{b}}$ & -0.25 & $-0.74^{\mathrm{a}}$ & $-0.81^{b}$ & & & \\
\hline $\mathrm{aC}$ & 0.11 & -0.03 & -0.09 & -0.49 & $-0.83^{\mathrm{b}}$ & -0.02 & $0.76^{\mathrm{a}}$ & $0.82^{\mathrm{b}}$ & $0.72^{\mathrm{a}}$ & 0.46 & $0.76^{\mathrm{a}}$ & $0.87^{\mathrm{b}}$ & $-0.77^{\mathrm{b}}$ & & \\
\hline $\mathrm{bC}$ & 0.17 & -0.04 & -0.15 & -0.59 & -0.93 & -0.04 & $0.86^{\mathrm{b}}$ & $0.94^{c}$ & $0.87^{\mathrm{b}}$ & 0.39 & $0.78^{\mathrm{b}}$ & $0.92^{c}$ & $-0.87^{\mathrm{b}}$ & $0.93^{c}$ & \\
\hline 1C & -0.12 & 0.19 & 0.07 & -0.43 & $-0.71^{\mathrm{a}}$ & -011 & $0.91^{c}$ & $089^{b}$ & $0.83^{\mathrm{b}}$ & 0.52 & 0.60 & $0.85^{\mathrm{b}}$ & $-0.78^{b}$ & $0.81^{\mathrm{b}}$ & $0.88^{\mathrm{b}}$ \\
\hline S. patula soil & Sand & Silt & Clay & DBD & $\mathrm{pH}$ & EC & SOC & GRSP & NT & $\mathrm{WSA}_{(0.25-2)}$ & $\mathrm{WSA}_{(2-5.6)}$ & $\mathrm{CO}_{2}$ & $\mathrm{Qm}$ & $\mathrm{aC}$ & bC \\
\hline Silt & $-0.70^{\mathrm{a}}$ & & & & & & & & & & & & & & \\
\hline Clay & $-0.69^{\mathrm{a}}$ & $-0.75^{\mathrm{a}}$ & & & & & & & & & & & & & \\
\hline DBD & $0.72^{\mathrm{a}}$ & $-0.77^{\mathrm{b}}$ & $-0.81^{\mathrm{b}}$ & & & & & & & & & & & & \\
\hline $\mathrm{pH}$ & 0.57 & -0.44 & -0.60 & 0.31 & & & & & & & & & & & \\
\hline EC & $-0.88^{\mathrm{b}}$ & $0.78^{\mathrm{b}}$ & $0.81^{\mathrm{b}}$ & -0.16 & $-0.69^{a}$ & & & & & & & & & & \\
\hline SOC & $-0.65^{\mathrm{a}}$ & $0.70^{\mathrm{a}}$ & $0.68^{\mathrm{a}}$ & -0.22 & $-0.94^{c}$ & 0.52 & & & & & & & & & \\
\hline GRSP & $-0.90^{c}$ & $0.83^{\mathrm{b}}$ & $0.87^{\mathrm{b}}$ & -0.49 & -0.54 & 0.08 & $0.63^{\mathrm{a}}$ & & & & & & & & \\
\hline NT & $-0.72^{\mathrm{a}}$ & $0.77^{\mathrm{b}}$ & $0.82^{\mathrm{b}}$ & -0.25 & $-0.90^{c}$ & 0.51 & $0.94^{\mathrm{c}}$ & 0.49 & & & & & & & \\
\hline $\operatorname{WSA}_{(0.25-2)}$ & $-0.81^{\mathrm{b}}$ & $0.72^{\mathrm{a}}$ & $0.80^{\mathrm{b}}$ & -0.11 & 0.12 & -0.38 & 0.02 & 0.22 & -0.14 & & & & & & \\
\hline $\mathrm{WSA}_{(2-5.6)}$ & $-0.86^{\mathrm{b}}$ & $0.80^{\mathrm{b}}$ & $0.76^{\mathrm{a}}$ & $-0.64^{\mathrm{a}}$ & -0.47 & 0.01 & 0.56 & $0.94^{c}$ & 0.51 & 0.08 & & & & & \\
\hline $\mathrm{CO}_{2}$ & $-0.91^{\mathrm{b}}$ & $0.80^{\mathrm{b}}$ & $0.84^{\mathrm{b}}$ & -0.03 & -0.20 & 0.33 & 0.38 & 0.17 & 0.44 & -0.28 & 0.23 & & & & \\
\hline Qm & $-0.72^{\mathrm{a}}$ & $0.75^{\mathrm{a}}$ & $0.73^{\mathrm{a}}$ & 0.58 & $0.66^{\mathrm{a}}$ & -0.18 & $-0.67^{\mathrm{a}}$ & -0.61 & -0.60 & 0.27 & $-0.70^{\mathrm{a}}$ & -0.11 & & & \\
\hline $\mathrm{aC}$ & -0.15 & 0.19 & 0.11 & -0.36 & -0.61 & -0.05 & 0.57 & 0.58 & 0.54 & 0.05 & 0.61 & -0.30 & $-0.83^{\mathrm{b}}$ & & \\
\hline $\mathrm{bC}$ & 0.19 & -0.15 & -0.21 & -0.42 & -0.56 & -0.15 & 0.58 & $0.70^{\mathrm{a}}$ & 0.53 & 0.16 & $0.72^{\mathrm{a}}$ & -0.18 & $-0.84^{\mathrm{b}}$ & $0.97^{c}$ & \\
\hline 1C & 0.36 & -0.22 & 0.10 & -0.36 & -0.44 & -0.50 & 0.27 & 0.62 & 0.39 & 0.30 & 0.54 & -0.46 & $-0.73^{\mathrm{a}}$ & 0.59 & $0.69^{\mathrm{a}}$ \\
\hline
\end{tabular}

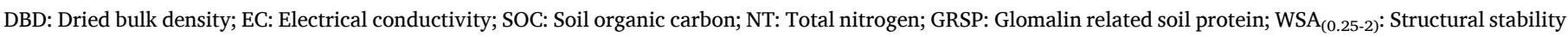

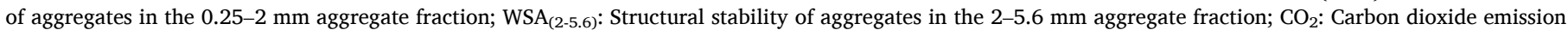
potential $\left(\mathrm{g} \mathrm{kg}^{-1}\right)$; Qm: Mineralization coefficient; aC: Aboveground biomass carbon; bC: Belowground biomass carbon; 1C: Litter biomass carbon.

${ }^{\mathrm{a}} \mathrm{p}<0.05$.

b $\mathrm{p}<0.01$.

c $\mathrm{p}<0.001$.

organic matter incorporation to soil. Significant variability $(\mathrm{p}<0.05)$ of $\mathrm{CO}_{2}$ and Qm values was found within $S$. fruticosa and $S$. patula soils at different depths and between them only at $0-5 \mathrm{~cm}$ depth.

Regardless the different content in SOC and GRSP between S. fruticosa and $S$. patula soils both parameters were significantly correlated ( $\mathrm{p}<0.001$ ) in both soils at both depths (Fig. 2a and b), as formerly reported by Caravaca et al. (2005), stating that glomalin may be produced also in soils with high salinity such as salt marshes. Other authors working on different types of soil also found significant relationships between SOC and GRSP (Rillig et al., 2001; Schindler et al., 2007; Emran et al., 2012). GRSP has been defined as an important part of stable soil organic carbon (Gispert et al., 2013; Vlček and Pohanka, 2020) and Gispert et al. (2018) found significant correlation of this major carbon pool with hardly mineralizable carbon compounds determined by pyrolysis-GC. Yet, Fokom et al. (2012) reported that GRSP plays an important role in the maintenance of soil structure and fertility. Its contribution to the stability of soil aggregates was early reported by Rillig (2004), inferring that dynamic processes of structure stability intensify the role of GRSP as a soil component to store recalcitrant organic carbon in microsites, thus enhancing soil carbon sequestration. In $S$. fruticosa soil, mean data of $\mathrm{WSA}_{(0.25-2 \mathrm{~mm})}$ and WSA $_{(2-5.6 \mathrm{~mm})}$ at $0-5$ and $5-20 \mathrm{~cm}$ depth plotted against GRSP showed significant fits ( $\mathrm{r}=0.83, \mathrm{p}<0.01$ and $\mathrm{r}=0.97, \mathrm{p}<0.001$ respectively) as can be seen in Fig. 3a, strengthening the role of glomalin in soil aggregate stability especially at high GRSP values. Different pictures were shown for $S$. patula soil with lower GRSP values and, consequently, lower WSA in the two aggregate fractions. When WSA was plotted against GRSP, the two regression lines of the $0.25-2$ and $2-5.6 \mathrm{~mm}$ aggregate fractions had $\mathrm{r}=0.66, \mathrm{p}<0.05$ and $\mathrm{r}=0.52$, $\mathrm{p}$ not significant respectively (Fig. 3b), and did neither indicate clear WSA difference between fractions nor depths, revealing much weaker soil structural stability in $S$. patula soil.

Two correlation matrices were tried by using both $S$. fruticosa and $S$. patula mean soil values along $0-20 \mathrm{~cm}$ depth and significant correlations among relevant soil parameters were marked at $\mathrm{p}<0.05$, $\mathrm{p}<$ 0.01 and $\mathrm{p}<0.001$ respectively (Table 2 ). In general, $S$. fruticosa soil showed higher correlation coefficients as to indicate stronger relationships between the studied parameters. In this soil, sand showed a significant positive correlation with DBD and $\mathrm{pH}(\mathrm{p}<0.01)$, probably related to potential conditions for surface crust and seal formation. Conversely, sand, DBD and $\mathrm{pH}$ were negatively and significantly correlated with silt, clay, SOC, GRSP, NT, WSA $(0,25-2), \mathrm{WSA}_{(2-5,6)} \mathrm{CO}_{2}$ and Qm (Table 2), suggesting possible impaired effects on these parameters (Wang et al., 2017; Bai et al., 2016). In addition, pH had high negative significant correlations with aC-S.fruticosa $(<0.01)$, bC-S. fruti$\cos a(\mathrm{p}<0.001)$ and $\mathrm{CC}-\mathrm{S}$. fruticosa $((\mathrm{p}<0.05)$, probably indicating that increasing alkalinity may affect abundant growth of succulent S. fruticosa (Redondo-Gómez et al., 2006). SOC, GRSP and NT were positively correlated with $\mathrm{CO}_{2}$, aC-S. fruticosa, bC-S. fruticosa and 1C-S. fruticosa, but negatively correlated with Qm (Table 2). This trend may recall the primary production of plants, increasing the amount of carbon recycled through the soil from above, belowground and litter inputs, later on depleted by mineralization processes (Cross and Sohi, 2011). According to Schmidt et al. (2011) the persistence of organic matter in soil should be more strictly related to a favorable environment than to itself biochemical properties, probably strengthening the assumption 

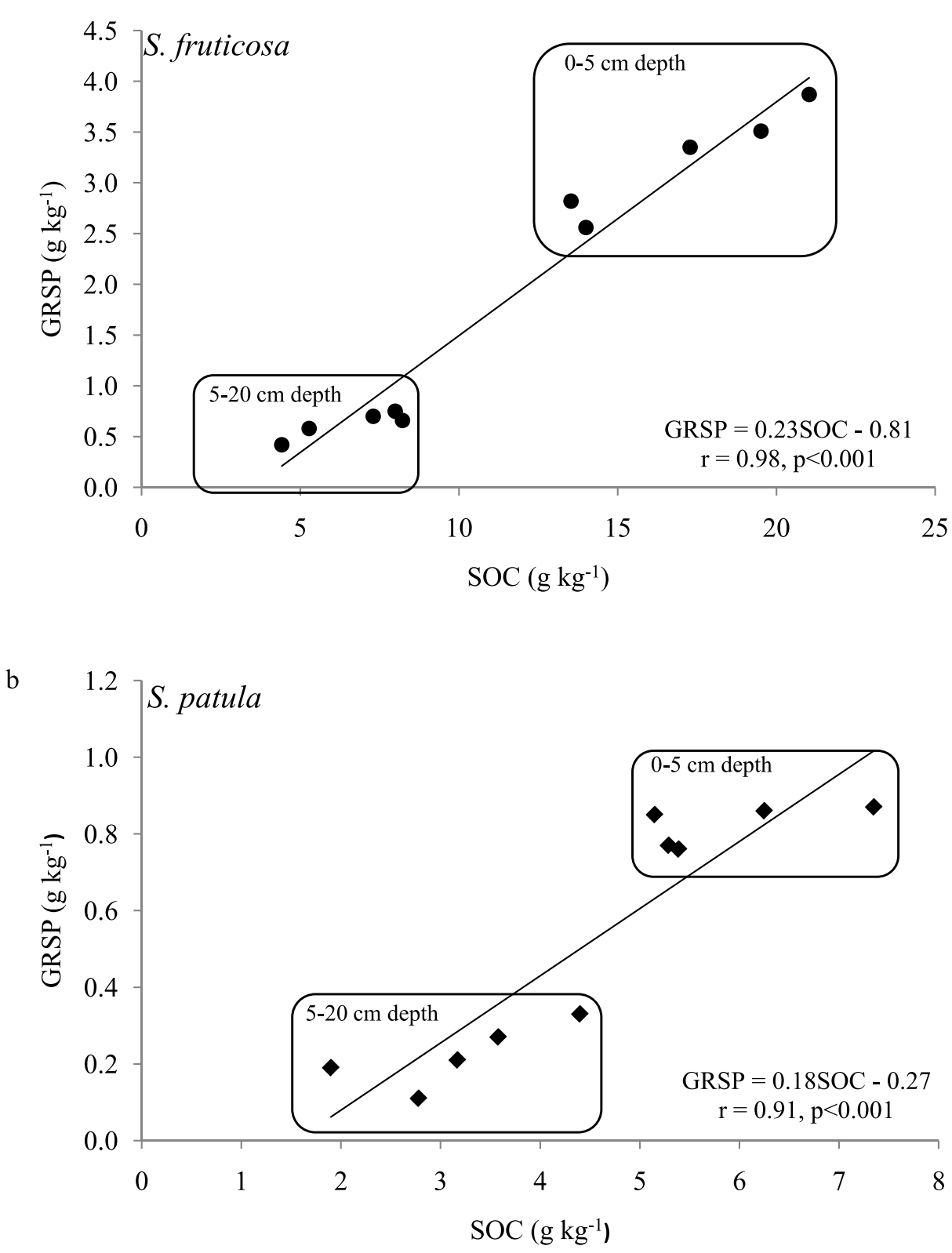

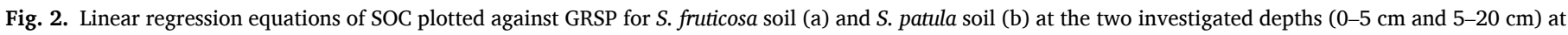
La Pletera salt marsh.

that $S$. fruticosa habitat is much more suitable for carbon storage. In this habitat, biomass carbon $(\mathrm{aC}, \mathrm{bC}, \mathrm{lC})$ was reciprocally and significantly correlated and showed significant positive correlations ( $<<0.01, \mathrm{p}<$ $0.001, \mathrm{p}<0.01$ respectively) with $\mathrm{CO}_{2}$ and significant negative correlation with Qm (Table 2).

Surprisingly, only the larger aggregate fraction of $S$. fruticosa soil was correlated with SOC, GRSP and NT. As SOC formation and stabilization dynamics is a complex biophysical process, it was reasonable to assume that larger amount of fresh SOC may be first deposited in larger aggregates and subsequently stored in smaller ones. An et al. (2010), found that the narrow range of $\mathrm{C}: \mathrm{N}$ ratio in micro-aggregates indicates that soil organic carbon in micro-aggregates is more stable than that in the macro-aggregates. Correlation patterns were somewhat similar in $S$. patula soil for sand and DBD though they were weaker or no significant for $\mathrm{pH}$ (Table 2). As above GRSP was correlated with WSA and Qm negatively correlated with aC, bC, 1C. Due to its phenological and physiological characteristics the $S$. patula habitat, common in many salt marshes, might affect a proper development of the edaphic layer thereby affecting the carbon storage capacity. In both soils the electrical conductivity (EC) did neither show correlations with parameters associated with organic carbon dynamics, nor with aggregate stability (Table 2). Nonetheless, Baustian et al. (2017) found negative significant relationships between salinity of surface waters and soil organic carbon accumulation rates in tidal marshes whilst Qu et al. (2018) stated that salinity may greatly inhibit carbon decomposition rates.

\subsection{Multiple linear regression models}

Multiple linear regression models (MLRMs) were established using mean values of both depths simultaneously for each soil to evaluate how 

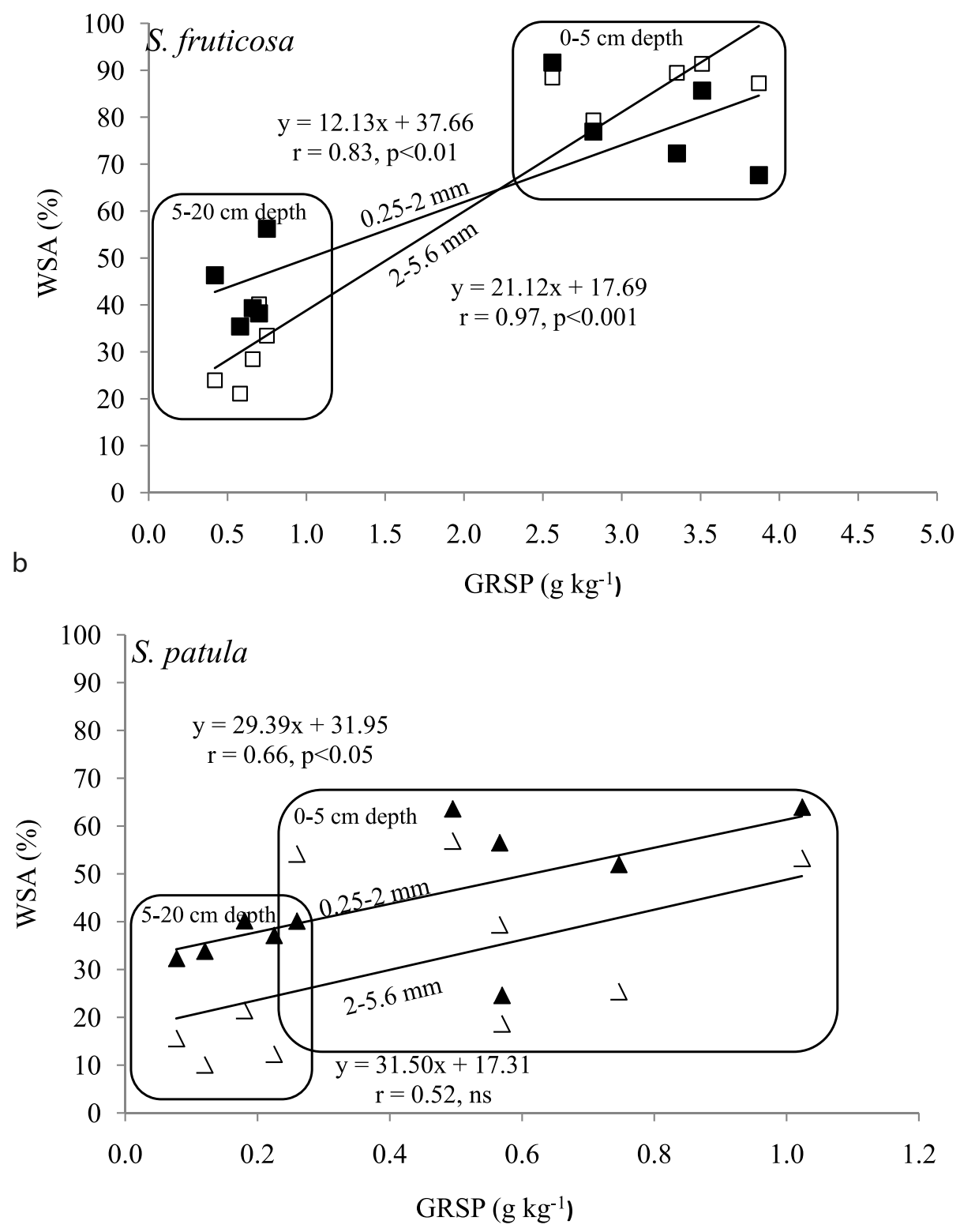

Fig. 3. Linear regression equations of GRSP plotted against WSA for both aggregate fractions of $S$. fruticosa soil (a) and $S$. patula soil (b) at the two investigated depths.

sand, silt+clay, DBD and $\mathrm{pH}$ influence the dependent variables SOC, GRSP, NT, $\mathrm{CO}_{2}, \mathrm{Qm}, \mathrm{WSA}_{(0.25-2)}$ and $\mathrm{WSA}_{(2-5.6)}$ and multiple correlation coefficients (R) were obtained. Results are shown in Table 3.

In $S$. fruticosa soil and $S$. patula soil, the multiple correlation coefficients $(\mathrm{R})$ were $0.95,0.96,0.97,0.95,0.46,0.92,0.93$ and 0.72 , $0.66,0.68,0.71,0.41,0.46,0.71$ for SOC, GRSP, NT, $\mathrm{CO}_{2}, \mathrm{Qm}, \mathrm{WSA}_{(0.25-}$ 2) and $\mathrm{WSA}_{(2-5.6)}$ respectively. Moreover, the MLRMs outputs show the standardized regression coefficients ( $\beta$ ) which dimensions, (marked in bold in Table 3), allow envisaging the claimed contribution of each independent variable in the prediction of the dependent variable. Accordingly, for $S$. fruticosa soil $\mathrm{pH}$ resulted negatively correlated and was the most relevant predictor of SOC ( $<0.001)$, GRSP ( $<<0.01)$, NT $(\mathrm{p}<0.01), \mathrm{CO}_{2}(\mathrm{p}<0.05), \mathrm{WSA}_{(0.25-2 \mathrm{~mm})}(\mathrm{p}<0.05)$, and $\mathrm{WSA}_{(2-5.6 \mathrm{~mm})}$ ( $<<0.05$ ), accounting for $91 \%, 92 \%, 93 \%, 91 \%, 85 \%$, and $86 \%$ of their variability $\left(\mathrm{R}^{2}\right)$, but $\mathrm{Qm}$ (Table 3). This may probably indicate that further increase in soil reaction may counteract SOC, NT and GRSP gain in these soil habitats (Bai et al., 2016) and likely points at reduction of soil porosity and gas circulation into soil by influencing carbon dioxide and both classes of aggregate stability (Tisdall and Oades, 1982; García-Orenes et al., 2005). Moreover, GRSP and $\mathrm{WSA}_{(2-5.6 \mathrm{~mm})}$ were positively correlated with silt+clay ( $\mathrm{p}<0.05)$, matching $92 \%$ of variability with $\mathrm{pH}$ (Table 3), and suggesting a favorable effect of finer particles to both secure soil aggregation and organic carbon protection (Hontoria et al., 2016). On average, the multiple correlation coefficients (R) for S. patula soil were in a range of $30-40 \%$ lower indicating lower fits between variables. In this soil DBD resulted the highest negatively correlated predictor for GRSP ( $\mathrm{p}<0.05)$, NT ( $\mathrm{p}<0.05), \mathrm{CO}_{2}(\mathrm{p}<0.05)$ and $\mathrm{WSA}_{(2-5.6 \mathrm{~mm})}(\mathrm{p}<0.05)$, and accounted for $43 \%, 46 \%, 50 \%$ and $48 \%$ of their variability (Table 3 ), whilst $\mathrm{pH}$ accounted for $52 \%$ of SOC variability $(\mathrm{p}<0.05)$. On the one hand, soil bulk density (the mass of soil per unit volume) has been reported as a component affecting carbon pool and aggregation especially in sandy textures (Throop et al., 2012). 
Table 3

Multiple linear regression models (MLRMs) showing the standardized regression coefficient $\beta$ (marked in bold) as predictors of each dependent variable.

\begin{tabular}{|c|c|c|c|}
\hline MLRMs & $\begin{array}{l}\text { MCCs } \\
(\mathrm{R})\end{array}$ & Predictor & $\mathrm{R}^{2}$ \\
\hline \multicolumn{4}{|l|}{ For $\underline{S . \text { fruticosa }}$ soil } \\
\hline $\begin{array}{l}\mathrm{Y}_{\mathrm{SOC}}=288.16-21.40 \mathrm{X}_{\mathrm{DBD}^{-}} \\
\quad 19.93 \mathrm{X}_{\mathrm{pH}}+3.29 \mathrm{X}_{\text {silt }+ \text { clay }}-0.88_{\text {sand }}\end{array}$ & 0.95 & $\mathrm{pH}$ & 0.91 \\
\hline $\begin{array}{l}\mathrm{Y}_{\mathrm{GRSP}}=43.02-4.03 \mathrm{X}_{\mathrm{pH}^{-}} \\
2.68 \mathrm{X}_{\mathrm{DBD}}+\mathbf{0 . 1 2} \mathrm{X}_{\text {silt }+ \text { clay }}-0.17 \mathrm{X}_{\text {sand }}\end{array}$ & 0.96 & $\begin{array}{l}\mathrm{pH} \\
\text { silt+clay }\end{array}$ & 0.92 \\
\hline $\begin{array}{l}\mathrm{Y}_{\mathrm{NT}}=5.93-0.88 \mathrm{X}_{\mathrm{pH}^{-}}-0.38 \mathrm{X}_{\mathrm{DBD}}+0.11 \mathrm{X}_{\text {silt }+ \text { clay }}{ }^{-} \\
0.03 \mathrm{X}_{\text {sand }}\end{array}$ & 0.97 & $\mathrm{pH}$ & 0.93 \\
\hline $\begin{array}{l}\mathrm{Y}_{\mathrm{CO}_{2}}=5.02-2.15 \mathrm{X}_{\mathrm{DBD}}-0.49 \mathrm{X}_{\mathrm{pH}}+0.09 \mathrm{X}_{\text {silt }+ \text { clay }} \\
\quad-0.02 \mathrm{X}_{\text {sand }}\end{array}$ & 0.95 & $\mathrm{pH}$ & 0.91 \\
\hline $\begin{array}{l}\mathrm{Y}_{\mathrm{Qm}}=-0.07-0.04 \mathrm{X}_{\mathrm{DBD}^{-}}-0.03 \mathrm{X}_{\mathrm{pH}}+0.02 \mathrm{X}_{\text {silt }+ \text { clay }}{ }^{-} \\
0.01 \mathrm{X}_{\text {sand }}\end{array}$ & 0.46 & - & 0.21 \\
\hline $\begin{array}{l}Y_{\text {WSA } 0.25-2}=206.31-55.50 \mathrm{X}_{\mathrm{DBD}^{-}} \\
\mathbf{5 5 . 4 4 X}_{\mathbf{p H}^{-}}+20.29 \mathrm{X}_{\text {silt }+ \text { clay }}-3.07 \mathrm{X}_{\text {sand }}\end{array}$ & 0.92 & $\mathrm{pH}$ & 0.85 \\
\hline $\begin{array}{l}Y_{\text {WSA 2-5.6 }}=649.14-85.79 \mathrm{X}_{\mathrm{DBD}^{-}} \\
\quad \mathbf{7 3 . 0 3 X}_{\mathrm{pH}}+\mathbf{1 2 . 5 0}_{\text {silt }+ \text { clay }}-0.98 \mathrm{X}_{\text {sand }}\end{array}$ & 0.93 & $\begin{array}{l}\mathrm{pH} \\
\text { silt+clay }\end{array}$ & 0.86 \\
\hline \multicolumn{4}{|l|}{ For $\underline{S . p a t u l a}$ soil } \\
\hline $\begin{array}{l}\mathrm{Y}_{\mathrm{SOC}}=74.07-8.13 \mathrm{X}_{\mathrm{pH}^{-}}-5.40 \mathrm{X}_{\mathrm{DBD}}+0.22 \mathrm{X}_{\text {silt }+ \text { clay }}- \\
0.08 \mathrm{X}_{\text {sand }}\end{array}$ & 0.72 & $\mathrm{pH}$ & 0.52 \\
\hline $\begin{array}{l}\mathrm{Y}_{\mathrm{GRSP}}=9.16-6.53 \mathrm{X}_{\mathrm{DBD}^{-}}-3.42 \mathrm{X}_{\mathrm{pH}}+0.44 \mathrm{X}_{\text {silt }+ \text { clay }^{-}} \\
0.11 \mathrm{X}_{\text {sand }}\end{array}$ & 0.66 & DBD & 0.43 \\
\hline $\begin{array}{l}\mathrm{Y}_{\mathrm{NT}}=3.27-2.24 \mathrm{X}_{\mathrm{DBD}^{-}}-0.53 \mathrm{X}_{\mathrm{pH}^{-}}+0.13 \mathrm{X}_{\text {silt }+ \text { clay- }} \\
\quad 0.02 \mathrm{X}_{\text {sand }}\end{array}$ & 0.68 & DBD & 0.46 \\
\hline $\begin{array}{l}\mathrm{Y}_{\mathrm{CO}_{2}}=4.61-2.05 \mathrm{X}_{\mathrm{DBD}^{-}}-0.33 \mathrm{X}_{\mathrm{pH}}+0.05 \mathrm{X}_{\text {silt }+ \text { clay }} \\
-0.01 \mathrm{X}_{\text {sand }}\end{array}$ & 0.71 & DBD & 0.50 \\
\hline $\begin{array}{l}\mathrm{Y}_{\mathrm{Qm}}=-0.01-0.03 \mathrm{X}_{\mathrm{DBD}^{-}}-0.03 \mathrm{X}_{\mathrm{pH}}+0.01 \mathrm{X}_{\text {silt }+ \text { clay }}^{-} \\
0.01 \mathrm{X}_{\text {sand }}\end{array}$ & 0.41 & - & 0.17 \\
\hline $\begin{array}{l}Y_{\text {WSA } 0.25-2}=340.08-223.02 X_{\mathrm{DBD}^{-}} \\
17.44 \mathrm{X}_{\mathrm{pH}}+7.45 \mathrm{X}_{\text {silt }+ \text { clay }}-3.07 \mathrm{X}_{\text {sand }}\end{array}$ & 0.46 & - & 0.21 \\
\hline $\begin{array}{l}Y_{\text {WSA 2-5.6 }}=808.17-91.21 \mathrm{X}_{\text {DBD }^{-}} \\
13.63 \mathrm{X}_{\mathrm{pH}}+4.30 \mathrm{X}_{\text {silt }+ \text { clay }}-1.54 \mathrm{X}_{\text {sand }}\end{array}$ & 0.71 & DBD & 0.50 \\
\hline
\end{tabular}

MLRMs: Multiple linear regression models; MCCs: Multiple correlation coefficients.

On the other hand, soil $\mathrm{pH}$ and texture may explain variation in carbon content (Bai et al., 2016). Linear regression equations already announced the importance of physical (sand, silt, clay, DBD) and chemical $(\mathrm{pH})$ parameters in the dynamics of relevant soil properties under both $S$. fruticosa and $S$. patula communities.

\subsection{Soil carbon stock, glomalin and carbon dioxide}

The soil carbon density (SCD) was calculated to obtain the soil carbon stock (SCS), expressed in $\mathrm{Mg} \mathrm{ha}^{-1}$ of each soil habitat at $0-5$ and $5-20 \mathrm{~cm}$ depth, taking into account the different thickness of the two soil layers. S. fruticosa soil showed $10.88 \pm 3.70 \mathrm{Mg} \mathrm{ha}^{-1}$ of SCS in the $0-5$ $\mathrm{cm}$ layer, $181 \%$ higher than $S$. patula soil, which showed $3.87 \pm 1.10 \mathrm{Mg}$ $\mathrm{ha}^{-1}$ (Table 4). In the same layer, GRSP in $S$. fruticosa soil was even higher increasing by $279 \%$ that of $S$. patula soil, overbearing as accumulator of potentially stable organic compounds. However, GRSP stock values were 2-8 times lower when compared to data found for midmountain shrub or prairie soils of NE Spain (Gispert et al., 2017). Treseder and Turner (2007) reported on possible effects of plant biomass, biomass allocation and litter quantity and quality on GRSP concentrations. It is known that GRSP is produced by arbuscular mycorrhizal fungi (AMF) in symbiosis with the majority of land plants (Gadkar and Rillig, 2006; Six et al., 2006), and that AMF may form symbioses with $82 \%$ of halophites (Evelin et al., 2009), which may imply that salinity slightly affects GRSP production. In fact, Zhang et al. (2017) reported that variation of EC had little effect on GRSP concentration, though finding negative correlations between GRSP and soil salinity. They had EC values in a range of $0.04-1.81 \mathrm{dS} \mathrm{m}^{-1}$ and GRSP values in a range of $0.70-4.30 \mathrm{~g} \mathrm{~kg}^{-1}$. It is therefore reasonable to assume that much higher EC values such that we found $\left(12.52 \pm 0.17 \mathrm{dS} \mathrm{m}^{-1}\right.$ in $S$. fruticosa soil and $11.22 \mathrm{dS} \mathrm{m}^{-1}$ in $S$. patula soil) might decrease GRSP content. Our GRSP values were $3.22 \pm 0.85 \mathrm{~g} \mathrm{~kg}^{-1}$ and $0.82 \pm 0.12 \mathrm{~g} \mathrm{~kg}^{-1}$ in $S$. fruticosa and $S$. patula soils, respectively. Kohler et al. (2010) indicated that the dispersive action of soluble salts may disrupt stable aggregates and induce release of older GRSP stocks. These numbers strengthen the importance of studies addressed to establish the relationships between plant species and carbon stocks in salt marshes (Kohler et al., 2017). As stated by Lovelock et al. (2004), GRSP may represent a large fraction of stable SOC. Although its composition is still partially unknown it has a relevant role by enriching the soil humic fraction and it is thought to enrich the stable organic carbon pool of soils (Gillespie et al., 2011). At higher SCS content in $S$. fruticosa soil corresponded higher potential $\mathrm{CO}_{2}$ production which was $24 \%$ higher than $S$. patula soil but almost irrelevant if considering the much higher SCS in S. fruticosa soil (Table 4). In fact, the carbon loss potential of $S$. patula soil, calculated as $\mathrm{CO}_{2} / \mathrm{SCS}$ ratio, increased by $162 \%$ with respect to $S$. fruticosa soil strengthening its poor ability to store carbon in soil. Also GRSP/SCS ratio was favorable to $S$. fruticosa soil outlining a clear capability for carbon storage (Table 4). SCS, GRSP and $\mathrm{CO}_{2}$ decreased substantially at 5-20 cm depth considering the larger soil thickness analyzed. Nonetheless, SCS and GRSP were $107 \%$ and $175 \%$ higher in $S$. fruticosa soil than S. patula soil, indicating that in the first $20 \mathrm{~cm}$ soil carbon compounds are prevalently enriched in the $S$. fruticosa plant community. Conversely, $\mathrm{CO}_{2}$ production increased by $38 \%$ in $S$. patula soil, enhancing the value of hardly mineralizable organic carbon in $S$. fruticosa carbon richer habitat (Table 4). The GRSP/SCS ratios at $5-20 \mathrm{~cm}$ were $9.32 \%$ and $6.98 \%$ for S. fruticosa and $S$. patula soils respectively, whilst $\mathrm{CO}_{2} / \mathrm{SCS}$ were $1.20 \%$ and $3.42 \%$ for the same soils suggesting a similar trend as above. Lovelock et al. (2004) found higher GRSP/SCS ratios varying from 27 to $42 \%$ in tropical soils and Qiang et al. (2018) found lower values close to $5 \%$ in subtropical mangroves, which would enhance the importance of S. fruticosa vegetation to soil organic matter stabilization and stable organic carbon input in La Pletera soil. By contrast, S. patula soil showed the highest contribution to carbon loss, on average $168 \%$ more than S. fruticosa soil all along the investigated depth.

Table 4

Mean values for $S$. fruticosa and $S$. patula soils of soil bulk density (DBD) and soil organic carbon (SOC) to obtain soil carbon density (SCD), soil carbon stock (SCS), and glomalin (GRSP) and carbon dioxide $\left(\mathrm{CO}_{2}\right)$ ratios to SCS at 0-5 and 5-20 cm depth in soil habitats at La Pletera salt marsh site.

\begin{tabular}{|c|c|c|c|c|c|c|c|c|}
\hline Soil & DBD & SOC & SCD & SCS & GRSP & GRSP/SCS & $\mathrm{CO}_{2}$ & $\mathrm{CO}_{2} / \mathrm{SCS}$ \\
\hline & $\left(\mathrm{g} \mathrm{cm}^{-3}\right)$ & $\left(\mathrm{g} \mathrm{kg}^{-1}\right)$ & $\left(\mathrm{g} \mathrm{cm}^{-3}\right)$ & $\left(\mathrm{Mg} \mathrm{ha}^{-1}\right)$ & $\left(\mathrm{Mg} \mathrm{ha}^{-1}\right)$ & $(\%)$ & $\left(\mathrm{Mg} \mathrm{ha}^{-1}\right)$ & $(\%)$ \\
\hline \multicolumn{9}{|l|}{$0-5 \mathrm{~cm}$ depth } \\
\hline$\overline{S . \text { fruticosa soil }}$ & $1.27 \pm 0.13$ & $17.07 \pm 5.83$ & $2.17 \pm 0.39$ & $10.88 \pm 3.70$ & $2.05 \pm 0.54$ & 18.84 & $0.31 \pm 0.02$ & 2.47 \\
\hline S. patula soil & $1.31 \pm 0.14$ & $5.89 \pm 1.68$ & $0.77 \pm 0.19$ & $3.87 \pm 1.10$ & $0.54 \pm 0.08$ & 13.95 & $0.25 \pm 0.03$ & 6.46 \\
\hline \multicolumn{9}{|l|}{ 5-20 cm depth } \\
\hline$\overline{S . ~ f r u t i c o s a ~ s o i l ~}$ & $1.34 \pm 0.28$ & $6.64 \pm 2.33$ & $0.89 \pm 0.21$ & $13.31 \pm 4.66$ & $1.24 \pm 0.41$ & 9.32 & $0.16 \pm 0.02$ & 1.20 \\
\hline S. patula soil & $1.35 \pm 0.19$ & $3.17 \pm 1.10$ & $0.43 \pm 0.14$ & $6.44 \pm 2.22$ & $0.45 \pm 0.17$ & 6.98 & $0.22 \pm 0.04$ & 3.42 \\
\hline
\end{tabular}

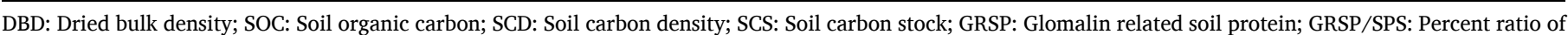

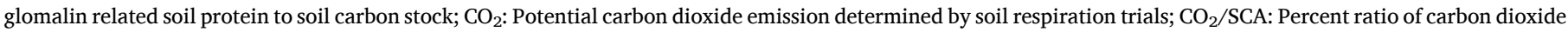
emission to soil carbon stock. 


\subsection{Principal components analysis}

The principal component analysis (PCA) was run by using mean data of 0-20 cm depth simultaneously for both soil habitats. A two components structure was obtained explaining the $75.92 \%$ of the total variance into variables. Indeed, PCA analysis is used to rank the analyzed variables and check those with higher percent weight of variance (Paniagua et al., 1999). Several authors (Doran and Parking, 1994; Paniagua et al., 1999; Shukla et al., 2006; Gispert et al., 2018) have proposed to rename the PCA components according to the associated variables and their significance into the investigated habitats. A graphical view of variables and habitats jointly may be observed in Fig. 4. The first component explaining $55.25 \%$ of the total variance into variables was named "carbon reserve and aggregation" because exhibited the most relevant variables related to soil carbon dynamics and structural stability of aggregates. Among others, this component had positive loadings on SOC (0.85), GRSP (0.93), WSA $_{(2-5.6 \mathrm{~mm})}(0.95)$, and negative loadings on DBD $(-0.81)$ and $\mathrm{pH}(-0.76)$. The total variance explained by the second component was $20.67 \%$ (63\% less than the first component). Positive loads were on $\mathrm{aC}$ (0.67) and bC (0.79) and negative loads on Qm (-0.62) and IC (-0.75) and was named "carbon input and output", suggesting organic matter turnover from above, below and litter carbon to progressive carbon incorporation into soil through processes of humification and mineralization carried out by microbial biomass activity. In Fig. 4 the "carbon reserve and aggregation" component is positively related with the most relevant soil properties of $S$. fruticosa soil and may be counteracted by $\mathrm{pH}$ and DBD mostly associated with $S$. patula soil. Similar findings arisen from the multiple regression models (MLRMs) when the independent variables $\mathrm{pH}$ and DBD were negatively correlated with the most relevant variables in both soils.

These results were also supported by matching components and associated variables with soil habitats in order to score the contribution of each soil habitat to variables grouped in each component (Fig. 5). Positive and negative values of the PCA scoring method may be interpreted as positive and negative contributions to a given component, namely a reliable indication of how each soil habitat may enrich or impoverish carbon stocks and also other soil properties. A first observation of Fig. 5 outlines the decreasing trend of the factor "carbon reserve and aggregation" from $S$. fruticosa soil to $S$. patula soil. The regression line for this component $(\mathrm{p}<0.05)$ corroborates this tendency. Moreover, the percent scores for $S$. fruticosa soil are all positive contribution to this component whilst $S$. patula soil shows all negative contributions, further indicating the poor role of this soil in the maintenance of sound soil properties. The scores for the second component "carbon input and output" were mainly positive for $S$. fruticosa soil, probably suggesting a fluctuating carbon dynamics, adequate to maintain a balance between nutrient inputs and soil structure stability (Gispert et al., 2018). By contrast, the $S$. patula soil scores were all negative even for the second component. This soil showed highest mineralization coefficient (Qm) with respect to SOC content, advising that less organic soils with weaker structure may be subjected to higher mineralization (Lal, 2005).

\section{Conclusion}

Both $S$. fruticosa and $S$. patula soils showed a proper growing dynamics with different primary production due to perennial or annual lifecycle respectively. Results suggested that $S$. fruticosa habitat allows a more conservative carbon dynamics which is unlikely to occur in

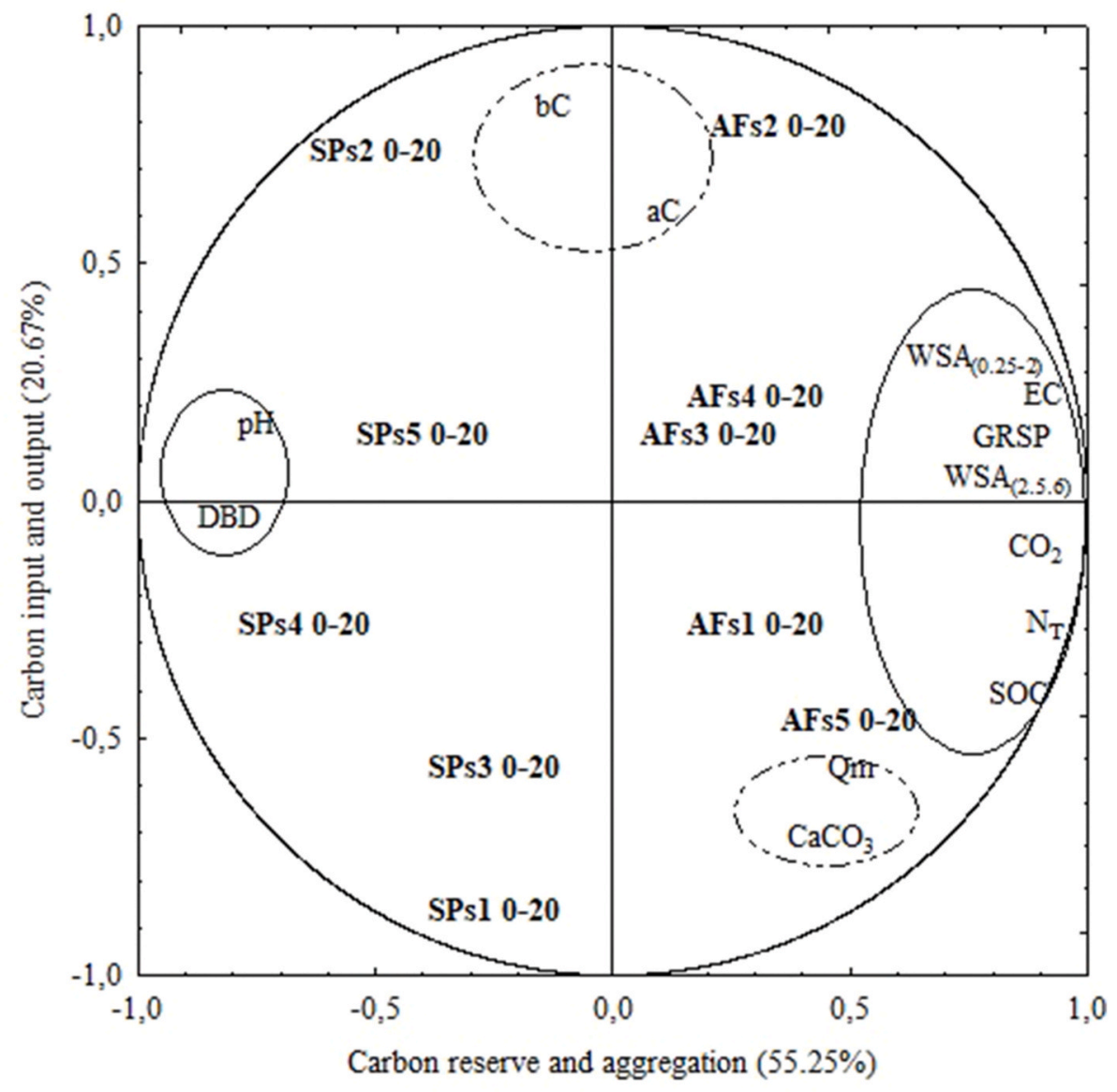

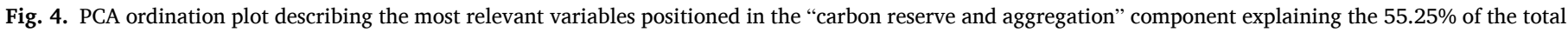
variance into variables and the "carbon input and output" component explaining $20.67 \%$ of the total variance into variables. 


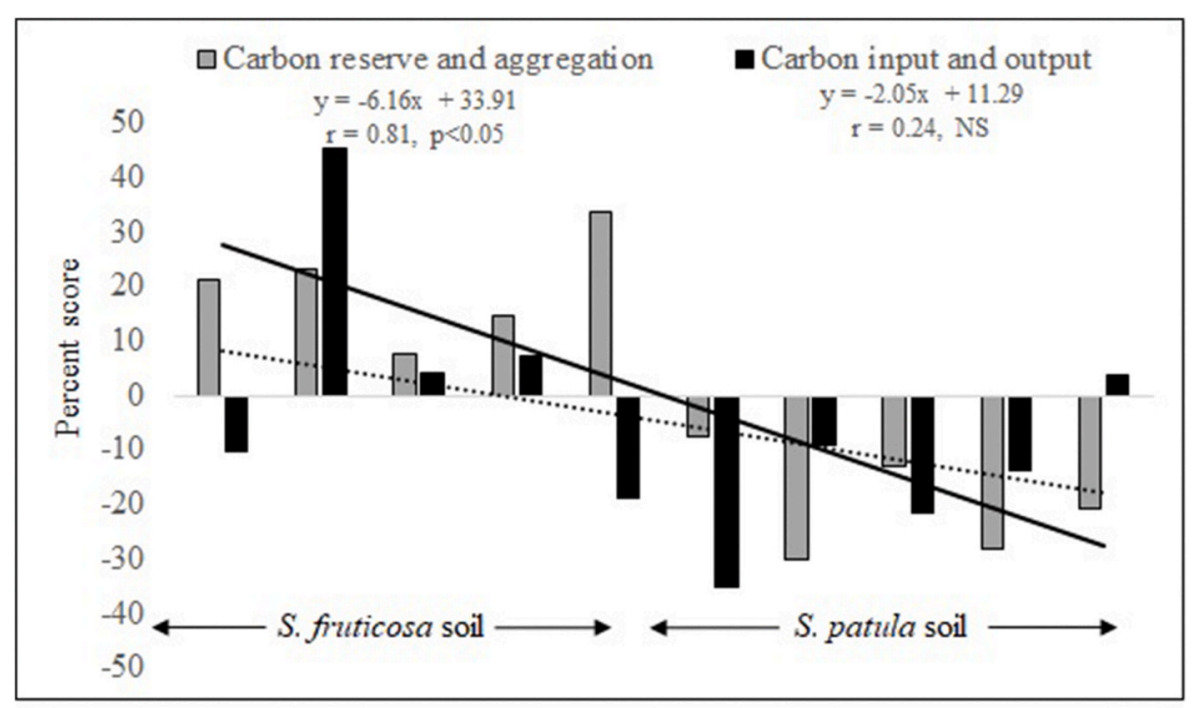

Fig. 5. The PCA scoring of components and related variables for each soil habitat: soil under $S$. fruticosa (SFs) and under $S$. patula (SPs). The bold regression line attests the preponderant role of SFs in the "carbon reserve and aggregation" component.

S. patula which is believed to renew its carbon stock year by year. Accordingly, soil properties under S. patula were much less favoured and affected soil organic carbon protection into aggregate microsites and consequent preservation from mineralization processes. S. fruticosa soil formed a soil profile with a differentiated organic horizon which granted more consistent soil physical and chemical properties, higher glomalin production and soil structural stability which in turn may enhance carbon storage in soil and reduce carbon loss via $\mathrm{CO}_{2}$. Even though the results of this work refer to soil properties and carbon dynamics at local scale, data illustrate contrasting ability of two different plant communities for organic carbon assimilation and may be valuable to abroad audience as a tool of comparison among soil type and vegetation species common in many salt marsh areas of the Mediterranean region. In the salt marsh area of La Pletera (NE Spain) efforts have been made to preserve this environment for its high ecosystem service. Data proved that marsh areas may give relevant contributions to carbon storage capacity increasing their ecological and societal value. Moreover, data appointed to Sarcocornia fruticosa L. (Scott) role with respect to Salicornia patula Duval Jouve in soil carbon accumulation and preservation with explicit indication that this habitat should be carefully protected.

\section{CRediT authorship contribution statement}

Maria Gispert: Conceptualization, Writing - review \& editing. Tetiana Kuliush: Formal analysis. Lina Dyachenko: Formal analysis. Mykola Kharytonov: Validation. Mohamed Emran: Formal analysis. Dolors Verdaguer: Investigation. Laura Llorens: Investigation. Lorena Carrasco-Barea: Investigation, Writing - review \& editing.

\section{Declaration of competing interest}

The authors declare that they have no known competing financial interests or personal relationships that could have appeared to influence the work reported in this paper.

\section{Acknowledgements}

Authors acknowledge the European Project LIFE 13 NAT/ES/001001 enabling the realization of this research work. The EU Erasmus ${ }^{+}$KA107 mobility and training project is also acknowledged for allowing the participation of $\mathrm{PhD}$ students in this research activity. The contribution of the Land and Water Technologies Department, Arid Lands Cultivation
Research Institute in glomalin measurements is also appreciated.

\section{References}

An, Shaoshan, Mentler, A., Mayer, H., Blum, W.E.H., 2010. Soil aggregation, aggregate stability, organic carbon and nitrogen in different soil aggregate fractions under forest and shrub vegetation on the Loess Plateau, China. Catena 81, 226-233.

Antisari, L.V., Ferronato, C., Pellegrini, E., Bascutti, F., Casolo, V., De Nobili, M., Vianello, G., 2017. Soil properties and plant community relationship in a salt marsh of the Grado and Marano lagoon (Northern Italy). J. Soils Sediments 17, 1862-1873.

Badosa, A., Boix, D., Brucet, S., López-Flores, R., Quintana, X.D., 2006. Nutrients and zooplankton composition and dynamics in relation to the hydrological pattern in a confined Mediterranean salt marsh (NE Iberian Peninsula). Estuar. Coast Shelf Sci. 66, 513-522.

Bai, Junhong, Zhang, Guangliang, Zhao, Qingqing, Lu, Qiongqiong, Jia, Jia, Cui, Baoshan, Liu, Xinhui, 2016. Depth-distribution patterns and control of soil organic carbon in coastal salt marshes with different plant covers. Sci. Rep. 6, 1-12.

Barbier, E.B., Hacker, S.D., Kennedy, C., Koch, E.W., Stier, A.C., Silliman, B.R., 2011. The value of estuarine and coastal ecosystem services. Ecol. Monogr. 81, 169-193.

Baustian, M.M., Stagg, C.L., Perry, C.L., Moss, L.C., Carruthers, T.J.B., Allison, M., 2017. Relationships between salinity and short-term soil carbon accumulation rates from marsh types across a landscape in the Mississippi River Delta. Wetlands 37, 313-324.

Bradford, M.M., 1976. A rapid and sensitive method for the quantitation of microgram quantities of protein utilizing the principle of protein-dye binding. Anal. Biochem. $72,248-254$.

Bremner, J.M., Mulvaney, C.S., 1986. Nitrogen in agricultural soils. In: Page, A.L., Miller, R.H., Keeney, D.R. (Eds.), Methods of Soil Analysis. American Society of Agronomy. Soil Science Society of America Publisher, Madison, WI, pp. 595-623.

Bromberg Gedan, K., Silliman, B.R., Bertness, M.D., 2009. Centuries of human-driven change in salt marsh ecosystems. Annu. Rev. Mar. Sci 1, 117-141.

Caravaca, F., Alguacil, M.M., Torres, P., Roldán, A., 2005. Plant type mediates rhizospheric microbial activities and soil aggregation in a semiarid Mediterranean salt marsh. Geoderma 124, 375-382.

Castellano, M.J., Mueller, K.E., Olk, D.C., Sawyer, J.E., Six, J., 2015. Integrating plant litter quality, soil organic matter stabilization, and the carbon saturation concept. Global Change Biol. 21, 3200-3209.

Castroviejo, S., 1990. Sarcocornia. In: Castroviejo, S., Laínz, M., López-González, G., Montserrat, P., Muñoz-Garmendia, F., Paiva, J., Villar, L. (Eds.), Flora Iberica: Plantas vasculares de la Península Ibérica e Islas Baleares. CSIC. Real Jardín Botánico, Madrid, pp. 528-531.

Cerdà, A., 1998. Soil aggregate stability under different Mediterranean vegetation types. Catena 32, 73-86.

Chastain, S.G., Kohfeld, K., Pellatt, M.G., 2018. Carbon stocks and accumulation rates in salt marshes of the Pacific Coast of Canada. Biogeosci. Discuss. 1-45.

Chmura, G.L., 2013. What do we need to assess the sustainability of the tidal salt marsh carbon sink? Ocean Coast Manag. 83, 25-31.

Č́źžková, H., Květ, J., Comín, F.A., Laiho, R., Pokorný, J., Pithart, D., 2011. Actual state of European wetlands and their possible future in the context of global climate change. Aquat. Sci. 75, 3-26.

Craft, C.S., 2007. Freshwater input structures soil properties, vertical accretion and nutrient accumulation of Georgia and U.S. tidal marshes. Limnol. Oceanogr. 52, 1220-1230.

Cross, A., Sohi, S.P., 2011. The priming potential of biochar products in relation to labile carbon contents and soil organic matter status. Soil Biol. Biochem. 43, 2127-2134. 
Curcó, A., Ibañez, C., Day, J.W., Prat, N., 2002. Net primary production and decomposition of salt marshes of the Ebro Delta (Catalonia, Spain). Estuaries 25, 309-324.

Deegan, L.A., Johnson, D.S., Warren, R.S., Peterson, B.J., Fleeger, J.W., Fagherazzi, S., Wollheim, W.M., 2012. Coastal eutrophication as a driver of salt marsh loss. Nature 490, 388-392.

Diaz-Guerra, L., Verdaguer, D., Gispert, M., Pardini, G., Font, J., Gonzalez, J.A., Peruzzi, E., Masciandaro, G., Llorens, L., 2018. Effects of UV radiation and rainfall reduction on leaf and soil parameters related to $\mathrm{C}$ and $\mathrm{N}$ cycles of a Mediterranean shrubland before and after a controlled fire. Plant Soil 424, 503-524.

Dommergues, Y., 1960. Notion of the coefficient of mineralization of soil carbon. Agron. Trop. 15, 54-60.

Doran, J.W., Parkin, T.B., 1994. Defining and assessing soil quality. In: Doran, J.W., Coleman, D.C., Bezdicek, D.F., Stewart, B.A. (Eds.), Defining Soil Quality for a Sustainable Environment. Special Publication No. 35. Soil Science Society America, Madison, WI, pp. 1-21.

Elsey-Quirk, T., Unger, V., 2018. Geomorphic influences on the contribution of vegetation to soil $\mathrm{C}$ accumulation and accretion in Spartina alterniflora marshes. Biogeosciences 15, 379-397.

Emran, M., Gispert, M., Pardini, G., 2012. Patterns of soil organic carbon, glomalin and structural stability in Mediterranean abandoned terraced lands. Eur. J. Soil Sci. 63, 637-649.

Evelin, H., Kapoor, R., Giri, B., 2009. Arbuscular mycorrhizal fungi in alleviation of salt stress: a review. Ann. Bot. 104, 1263-1280.

Fokom, R., Adamou, S., Teugwa, M.C., Boyogueno, A.D.B., Nana, W.L., Ngonkeu, M.E.L., Tchameni, N.S., Nwaga, D., Ndzomo, G.T., Zollo, P.H.A., 2012. Glomalin related soil protein, carbon, nitrogen and soil aggregate stability as affected by land use variation in the humid forest zone of south Cameroon. Soil Tillage Res. 120, 69-75.

Forster, J.C., 1995. Soil physical analysis. In: Alef, K., Nannipieri, P. (Eds.), Methods in Soil Microbiology and Biochemistry. Academic Press, London, pp. 79-87.

Gadkar, V., Rillig, M., 2006. The arbuscular mycorrhizal fungal protein glomalin is a putative homolog of heat shock protein 60. FEMS (Fed. Eur. Microbiol. Soc.) Microbiol. Lett. 263, 93-101.

García-Orenes, F., Guerrero, C., Mataix-Solera, J., Navarro-Pedreño, J., Gómez, I., Mataix-Beneyto, J., 2005. Factors controlling the aggregate stability and bulk density in two different degraded soils amended with biosolids. Soil Tillage Res. 82, 65-76.

Gasparri, R., Casavecchia, S., Galié, M., Soriano, P., Estrelles, E., Biondi, E., 2016. Germination pattern of Salicornia patula as an adaptation to environmental conditions of the specific populations. Plant Sociol. 53, 91-104.

Gesti, J., 2019. Plantes d'ambients especials: les maresmes litorals. Milfulles 2, 29-35.

Gillespie, A.W., Farrel, R.E., Walley, F.L., Ross, A.R.S., Leiweber, P., Eckfardt, K., Regier, T.Z., Blyth, R.I.R., 2011. Glomalin related soil protein contains nonmycorrhizal-related heat-stable proteins, lipids and humic materials. Soil Biol. Biochem. 43, 766-777.

Gispert, M., Emran, M., Pardini, G., Doni, S., Ceccanti, B., 2013. The impact of land management and abandonment on enzymatic activity, glomalin content and aggregate stability. Geoderma 203, 51-61.

Gispert, M., Pardini, G., Colldecarrera, M., Emran, M., Doni, S., 2017. Water erosion and soil properties patterns along selected rainfall events in cultivated and abandoned terraced fields under renaturalization. Catena 155, 114-126.

Gispert, M., Pardini, G., Emran, M., Doni, S., Masciandaro, G., 2018. Seasonal evolution of soil organic matter, glomalin and enzymes and potential for carbon storage after land abandonment and renaturalization processes in soils of NE Spain. Catena 162, 402-413.

González-Alcaraz, M.N., Egea, C., Jiménez-Cárceles, F.J., Párraga, I., MaríaCervantes, A., Delgado, M.J., Álvarez-Rogel, J., 2012. Storage of organic carbon, nitrogen and phosphorus in the soil-plant system of Phragmites australis stands from a eutrophicated Mediterranean salt marsh. Geoderma 185-186, 61-72.

Grogan, P., 1998. CO2 flux measurement using soda lime: the appropriate correction for water formed during CO2 adsorption. Ecology 79, 1467-1468.

Hontoria, C., Gómez-Paccard, C., Mariscal-Sancho, I., Benito, M., Pérez, J., Espejo, R., 2016. Aggregate size distribution and associated organic C and N under different tillage systems and Ca-amendment in a degraded Ultisol. Soil Tillage Res. 160, 42-52.

Hopkins, F.M., Filley, T.R., Gleixner, G., Lange, M., Top, S.M., Trumbore, S.E., 2014. Increased belowground carbon inputs and warming promotes loss of soil organic carbon through complementary microbial response. Soil Biol. Biochem. 76, 57-69.

Howe, A.J., Rodríguez, J.F., Saco, P.M., 2009. Surface evolution and carbon sequestration in disturbed and undisturbed wetland soils of the Hunter estuary, southeast Australia. Estuar. Coast Shelf Sci. 84, 75-83.

Ibañez, C., Day, J.W., Pont, D., 1999. Primary production and decomposition of wetlands of the Rhone delta, France: interactive impacts of human modifications and relative sea level rise. J. Coast Res. 15, 717-731.

Ibañez, C., Curcó, A., Day, J.W., Prat, N., 2000. Structure and productivity of microtidal mediterranean coastal marshes. In: Weinstein, M.P., Kreeger, D.A. (Eds.), Concepts and Controversies in Tidal Marsh Ecology. Springer Netherlands, pp. 107-136.

Jobbágy, E.G., Jackson, R.B., 2000. The vertical distribution of soil organic carbon and its relation to climate and vegetation. Ecol. Appl. 10, 423-436.

Keith, H., Wong, S.C., 2006. Measurement of soil $\mathrm{CO}_{2}$ efflux using soda lime absorption: both quantitative and reliable. Soil Biol. Biochem. 38, 1121-1131.

Kemper, W.D., Rosenau, R.C., 1986. Aggregate stability and size distribution. In: Klute, A. (Ed.), Methods of Soil Analysis, Part 1, second ed. American Society of Agronomy, Madison, WI, pp. 425-441. Agronomy Monograph No. 9.
Kirwan, M.L., Guntenspergen, G.R., 2012. Feedbacks between inundation, root production, and shoot growth in a rapidly submerging brackish marsh. J. Ecol. 100, 764-770.

Kohler, J., Caravaca, F., Roldán, A., 2010. An AM fungus and a PGPR intensify the adverse effect of salinity on the stability of rhizosphere soil aggregates of Lactuca sativa. Soil Biol. Biochem. 42, 429-434.

Kohler, J., Roldán, A., Campoy, M., Caravaca, F., 2017. Unravelling the role of hyphal networks from arbuscular mycorrhizal fungi in aggregate stabilization of semiarid soils with different textures and carbonate contents. Plant Soil 410, 273-281.

Lal, R., 2005. Soil erosion and carbon dynamics. Soil Tillage Res. 81, 137-142.

Lal, R., 2008. Carbon sequestration. Phil. Trans. Royal Soc.. B 363, 815-830.

Lefeuvre, J.C., Laffaille, P., Feunteun, E., Bouchard, V., Radureau, A., 2003. Biodiversity in salt marshes: from patrimonial value to ecosystem functioning. The case study of the Mont-Saint-Michel bay. Comptes Rendus Biol. 326, 125-131.

Leuven, J.R.F.W., Pierik, H.J., van der Vegt, M., Bouma, T.J., Kleinhans, M.G., 2019. Sealevel-rise-induced threats depend on the size of tide-influenced estuaries worldwide. Nat. Clim. Change 9, 986-992.

Lovelock, C.E., Wright, S.F., Clark, D.A., Ruess, R.W., 2004. Soil stocks of glomalin produced by arbuscular mycorrhizal fungi across a tropical rain forest landscape. J. Ecol. 92, 278-287.

Macreadie, P.I., Hughes, A.R., Kimbro, D.L., 2013. Loss of ‘Blue Carbon' from coastal salt marshes following habitat disturbance. PloS One 8, 1-8.

Marani, M., D’Alpaos, A., Lanzoni, S., Santalucia, M., 2011. Understanding and predicting wave erosion of marsh edges. Geophys. Res. Lett. 38, L21401. https://doi. org/10.1029/2011GL048995.

Mcleod, E., Chmura, G.L., Björk, M., Bouillon, S., Duarte, C.M., Lovelock, C., Salm, R. Schlesinger, W., Silliman, B., 2011. A blueprint for Blue carbon: towards an improved understanding of the role of vegetated coastal habitats in sequestering $\mathrm{CO}_{2}$. Front. Ecol. Environ. 9, 552-560.

Menció, A., Casamitjana, X., Mas-Pla, J., Coll, N., Martinoy, M., Pascual, J., Quintana, X. D., 2017. Groundwater dependence of coastal lagoons: the case of la Pletera salt marshes (NE Catalonia). J. Hydrol. 552, 793-806.

Mitsch, W.J., Bernal, B., Nahlik, A.M., Mander, U., Zhang, L., Anderson, C.J., Jørgensen, S.E., Brix, H., 2013. Wetlands, carbon, and climate change. Landsc. Ecol. 28, 583-597.

Nichols, K.A., Wright, S.F., 2005. Comparison of glomalin and humic acid in eight native U.S. soils. Soil Sci. 170, 985-997.

Oades, J.M., 1984. Soil organic matter and structural stability: mechanisms and implications for management. Plant Soil 76, 319-337.

Paniagua, A., Kammerbauer, J., Avedillo, M., Andrews, A.M., 1999. Relationship of soil characteristics to vegetation successions on a sequence of degraded and rehabilitated soils in Honduras. Agric. Ecosyst. Environ. 72, 215-225.

Pei, Lixin, Ye, Siyuan, Yuan, Hongming, Pei, Shaofeng, 2019. Glomalin-related soil protein distributions in the wetlands of the Liaohe Delta, Northeast China: implications for carbon sequestration and mineral weathering of coastal wetlands. Limnol. Oceanogr. https://doi.org/10.1002/lno.11364.

Pendleton, L., Donato, D.C., Murray, B.C., Crooks, S., Jenkins, W.A., Sifleet, S., Craft, C., Fourqurean, J.W., Kauffman, J.B., Marbà, N., Megonigal, P., Pidgeon, E., Herr, D., Gordon, D., Balder, A., 2012. Estimating global "Blue carbon" emissions from conversion and degradation of vegetated coastal ecosystems. PloS One 7, 1-7.

Qiang, Wanga, Lua, Haoliang, Chenb, Jingyan, Honga, Hualong, Liua, Jingchun, Lia, Junwei, Yan, Chongling, 2018. Spatial distribution of glomalin-related soil protein and its relationship with sediment carbon sequestration across a mangrove forest. Sci. Total Environ. 613, 548-556.

Qu, Wendi, Li, Juanyong, Han, Guangxuan, Wu, Haitao, Song, Weimin, Zhang, Xiaoshuai, 2018. Effect of salinity on the decomposition of soil organic carbon in a tidal wetland. J. Soils Sediments. https://doi.org/10.1007/s11368-0182096-y.

Quintana, X.D., 2002. Estimation of water circulation in a mediterranean salt-marsh and its relationship with flooding causes. Limnética 21, 25-35.

Redondo-Gómez, S., Wharmbya, C., Castillo, J.M., Mateos-Naranjo, E., Luque, C.J., de Cires, A., Luque, T., Davy, A.J., Enrique Figueroa, M., 2006. Growth and photosynthetic responses to salinity in an extreme halophyte, Sarcocornia fruticosa. Physiol. Plantarum 128, 116-124.

Rillig, M.C., 2004. Arbuscular mycorrhizae, glomalin, and soil aggregation. Can. J. Soil Sci. 84, 355-363.

Rillig, M.C., Wright, S.F., Nichols, K.A., Schmidt, W.F., Torn, M.S., 2001. Large contributions of arbuscular mycorrhizal fungi to soil carbon pools in tropical soils. Plant Soil 233, 167-177.

Saintilan, N., Rogers, K., Mazumder, D., Woodroffe, C., 2013. Allochthonous and autochthonous contributions to C accumulation and C store in southeastern Australian coastal wetlands. Estuar. Coast Shelf Sci. 128, 84-93.

Šajna, N., Regvar, M., Kaligari, S., Škvorc, E., 2013. Germination characteristics of Salicornia patula Duval-Jouve, S. emerici Duval-Jouve, and S. veneta Pign. et Lausi and their occurrence in Croatia. Acta Bot. Croat. 72, 347-358.

Scarton, F., Day, J.W., Rismondo, A., 2002. Primary production and decomposition of Sarcocornia fruticosa (L.) Scott and Phragmites australis trin. Ex stendel in the Po delta, Italy. Estuaries 25, 325-336.

Schindler, F.V., Mercer, E.J., Rice, J.A., 2007. Chemical characteristics of glomalinrelated soil protein (GRSP) extracted from soils of varying organic matter content. Soil Biol. Biochem. 39, 320-329.

Schmidt, M.W.I., Torn, M.S., Abiven, S., Dittmar, T., Guggemberger, G., Janssens, I.A., Kleber, M., Kögel-knabner, I., Lehmann, J., Manning, D.A.C., Nannipieri, P., Rasse, D.P., Weiner, S., Trumbore, S.E., 2011. Persistence of soil organic matter as an ecosystem property. Nature $478,49-56$. 
Schukla, M.K., Lal, R., Ebinger, M., 2006. Determining soil quality indicators by factor analysis. Soil Tillage Res. 87, 194-204.

Setia, R., Marschner, P., Baldock, J., Chittleborough, D., Verma, V., 2011. Relationships between carbon dioxide emission and soil properties in salt-affected landscapes. Soil Biol. Biochem. 43, 667-674.

Silvestri, S., D’Alpaos, A., Nordio, G., Carniello, L., 2018. Anthropogenic modifications can significantly influence the local mean sea level and affect the survival of salt marshes in shallow tidal systems. J. Geophys. Res.: Earth Surface 123, 996-1012.

Six, J., Frey, S.D., Thiet, R.K., Batten, K.M., 2006. Bacterial and fungal contributions to carbon sequestration in agroecosystems. Soil Sci. Soc. Am. J. 70, 555-569.

Soil Survey Staff, 2014. In: Keys to Soil Taxonomy, 12 ed. USDA-Natural Resources Conservation Service, Washington DC, p. 399.

Spencer, K.L., Harvey, G.L., 2012. Understanding system disturbance and ecosystem services in restored saltmarsh: integrating physical and biogeochemical processes. Estuar. Coast Shelf Sci. 106, 23-32.

Throop, H.L., Archer, S.R., Monger, H.C., Waltman, S., 2012. When bulk density methods matter: implications for estimating soil organic carbon pools in rocky soils. J. Arid Environ. 77, 66-71.

Tisdall, J.M., Oades, J., 1982. Organic matter and water-stable aggregates in soils. Eur. J. Soil Sci. 33, 141-163.

Totsche, K.U., Amelung, W., Gerzabek, M.H., Guggenberger, G., Klumpp, E., Knief, C., Lehndorff, E., Mikutta, R., Peth, S., Prechtel, A., Ray, N., Kogel-Knabner, I., 2018. Microaggregates in soils. J. Plant Nutr. Soil Sci. 181, 104-136.

Treseder, K.K., Turner, K.M., 2007. Glomalin in ecosystems. Soil Sci. Soc. Am. J. 71, $1257-1266$.

Tripathee, R., Schäfer, K.V.R., 2015. Above- and belowground biomass allocation in four dominant salt marsh species of the Eastern United States. Wetlands 35, 21-30.
Unger, V., Elsey-Quirk, T., Sommerfield, C., Velinsky, D.J., 2016. Stability of organic C accumulating in Spartina alterniflora dominated marshes of the mid-Atlantic U.S.A. Estuarine Coast. Shelf Sci. 182, 179-189.

Valdés, B., Castroviejo, S., 1990. Salicornia. In: Castroviejo, S., Laínz, M., LópezGonzález, G., Montserrat, P., Muñoz-Garmendia, F., Paiva, J., Villar, L. (Eds.), Flora Iberica: Plantas vasculares de la Península Ibérica e Islas Baleares. CSIC. Real Jardín Botánico, Madrid, pp. 531-534.

Van de Broek, M., Temmerman, S., Merckx, R., Govers, G., 2016. Controls on soil organic carbon stocks in tidal marshes along an estuarine salinity gradient. Biogeosciences $13,6611-6624$.

Vlček, V., Pohanka, M., 2020. Glomalin - an interesting protein part of the soil organic matter. Soil Water Res. 15, 67-74.

Walkley, A., Black, I.A., 1934. An examination of the Degtjareff method for determining soil organic matter and a proposed modification of the chromic acid titration method. Soil Sci. 37, 29-38.

Wang, Hongqing, Piazza, S.C., Sharp, L.A., Stagg, C.L., Couvillon, B.R., Steyer, G.D., McGinnis, T.E., 2017. Determining the Spatial Variability of Wetland Soil Bulk Density, Organic Matter, and the Conversion Factor between Organic Matter and Organic Carbon across Coastal Louisiana. U.S.A. J. Coast. Res. 33, 507-517.

WenYang, Lu, Xia, Zhu, Zhihong, Jiang, Lifen, Cheng, Xiaoli, An, Shuqing, 2019. Shift in soil organic carbon and nitrogen pools in different reclaimed lands following intensive coastal reclamation on the coasts of eastern China. Sci. Rep. 9, 1-10. https://doi.org/10.1038/s41598-019-42048-6.1-10.

Zhang, Zhonghua, Wang, Qiong, Wang, Hua, Nie, Siming, Liang, Zhengwei, 2017. Effects of soil salinity on the content, composition, and ion binding capacity of glomalinrelated soil protein (GRSP). Sci. Total Environ. 581, 657-665. 